Revista Eletrônica de Direito Processual - REDP.

Rio de Janeiro. Ano 11. Volume 18. Número 1. Janeiro a Abril de 2017

Periódico Quadrimestral da Pós-Graduação Stricto Sensu em Direito Processual da UERJ

Patrono: José Carlos Barbosa Moreira. ISSN 1982-7636. pp. 68-122

wWw.redp.uerj.br

\title{
FACING UP TO MULTINATIONALCOMPLEX LITIGATION \\ IN THE UNITED STATES ${ }^{1 \_2}$
}

Ángel R. Oquendo

George J. and Helen M. England Professor of Law, University of Connecticut; CAPES Visiting Professor from Abroad, Federal \& State Universities of Rio de Janeiro; DAAD Visiting Professor, Free University of Berlin. Ph.D., M.A. (Philosophy), A.B. (Economics and Philosophy), Harvard University; J.D., Yale Law School. The author himself has translated the quoted non-English texts and vouches for the accuracy of the translation. He would like to thank Ben Haldeman and Claudia Schubert for their invaluable contribution to the development of the ideas of this article. oquendo@zedat.fu-berlin.de

RESUMO: Uma Corte Federal deve buscar a presença de estrangeiros em uma global class action, com vistas a obter uma reparação monetária, com a mente aberta. Deve mantê-los consigo enquanto concluem, mediante a análise profunda do direito comparado, o que o Judiciário da nação de origem daquele indivíduo decidiria ao final. Por exemplo, os membros da América Latina deveriam permanecer na medida em que fosse deferido a um juiz norte-americano o dever de chegar àquela conclusão. $\mathrm{E}$, como consequência da res iudicata, eles não conseguiram obter o rejulgamento da causa em seus países após serem derrotados no mérito nos Estados Unidos. Particularmente, um Tribunal de qualquer um dos outros sete países representantes da região (México, Brasil, Venezuela, Colômbia, Panamá, Peru e Equador) provavelmente entenderia que o julgamento proferido nos Estados Unidos respeitou o devido processo legal, assim como os demais requisitos para a sua homologação. Ou seja, sustentaria aqueles que não se submeteram à jurisdição nacional não poderiam, legitimamente, se queixar do efeito preclusivo da coisa julgada, eis que tiveram a possibilidade de lançar os esforços possíveis, sobre a

\footnotetext{
${ }^{1}$ Artigo recebido em 19/04/2017 sob dispensa de revisão.

${ }^{2}$ An earlier version appeared in 16 WAShington U. GLOBAL Studies L. REv. 71-124 (2017).
} 
Revista Eletrônica de Direito Processual - REDP.

Rio de Janeiro. Ano 11. Volume 18. Número 1. Janeiro a Abril de 2017

Periódico Quadrimestral da Pós-Graduação Stricto Sensu em Direito Processual da UERJ

Patrono: José Carlos Barbosa Moreira. ISSN 1982-7636. pp. 68-122

www.redp.uerj.br

ação de seus representantes, para obter uma compensação, teriam se beneficiado de numerosos

controles da justiça da decisão, e teriam obtido semelhante resultado em sua terá natal baseado

em um processo conduzido por alguém sem sua autorização. Os juízes dos Estados Unidos deverão deliberar, de maneira aprofundada, sobre se querem receber cidadãos de qualquer outro lugar do mundo para litigar.

PALAVRAS-CHAVE: Ações complexas, partes estrangeiras, ações coletivas, execução de sentenças estrangeiras.

ABSTRACT: A federal court should approach the presence of foreigners in a global class action for monetary relief with an openmind. It should keep them in so long as it can conclude, upon a reflective comparative law analysis, that the judiciary in theirnationof origin would upholdtheultimate ruling.For example, Latin American absent class members should normally stay on board inasmuchas virtually every jurisdictionin their regionwould allow a U.S. adjudicator to arrive at this conclusion.Accordingly, they would fail, on grounds of res judicata, if they ever tried to re-litigate the matter back home upon a defeat on the merits in the United States. In particular, a tribunal from any one of seven representative regional countries (Mexico, Brazil, Venezuela, Colombia, Panama, Peru, and Ecuador) wouldmost probably find such a U.S.judgment consistent with local due process, as well as with the remaining requirements for recognition.In other words, it would hold thatabsentees stemming from its jurisdictional territory could not legitimately complain about the preclusive effect since they would have free ridden on the efforts of their representatives with a chance at compensation, would have benefited from numerous fairness controls, and could have similarly faced preclusion in their homeland based on a suit prosecuted by someone else without their authorization.Judges in the United States should engage in a similar in-depth deliberationto decide whether to welcomecitizens from anywhere else in the worldto the litigation.

KEYWORDS: Complex litigation, foreign litigants, class actions, enforcement of foreign judgments. 
Revista Eletrônica de Direito Processual - REDP.

Rio de Janeiro. Ano 11. Volume 18. Número 1. Janeiro a Abril de 2017

Periódico Quadrimestral da Pós-Graduação Stricto Sensu em Direito Processual da UERJ

Patrono: José Carlos Barbosa Moreira. ISSN 1982-7636. pp. 68-122

www.redp.uerj.br

\section{INTRODUCTION}

The internationalization of businessand the diversification of thepopulation have profoundly impacted the law.Ever more often, the U.S. judiciary hashad to adjudicate claims stakedbyforeigners, whomay or may not reside in the United States, and has had to face the corresponding logistical and cultural challenges. ${ }^{3}$ In class actions, it has additionally confronted the problem of not knowing whether its ultimate ruling wouldattain recognition in the event of re-litigation abroad inforumspossessingdifferentsystems of collective adjudication. ${ }^{4}$ Under these circumstances, the temptation simply to dismissforeign absent class members from the suit looms large.

This article will arguethat, particularly when dealing with a global class, which encompasses a sizeable proportion of non-citizens, federal courts shouldactually engage in intense comparative reflection in order to determine whether their counterparts in other nations would or would not enforce their judgments.Concentrating on Latin America, it willmaintain that they should keep apassive claimant on board so long as his or her jurisdiction of origin could appreciate U.S. class actions as fair and compatible with local fundamental legal principles.A similar approach suggests itself with respect to absentees from other parts of the world.

Consequently, the article will itself assesswhethertribunalsin Latin America would likely uphold a final decision in a damages class suit lodged in the United States.In particular, it will ascertainwhether they would do so if any of the absent Latin American class members instituted an essentially identicalcomplaint back home upon an adverse definitive determination north of the border.The discussion will consider Latin America generally, but focus specifically ona representative sample of seven countries:Mexico, Brazil, Venezuela, Colombia, Panama, Peru, and Ecuador.It will determine the likelihood of judicial enforcement in the region as a whole and in these specific jurisdictions.

${ }^{3}$ See, e.g., Sosa v. Álvarez-Machaín, 542 U.S. 692 (2004).

${ }^{4}$ See, e.g., Anwar v. Fairfield Greenwich, Ltd., 289 F.R.D. 105, 120 (S.D.N.Y. 2013), partially aff'd sub. nom. Lomeli v. Sec. \& Inv. Co. Bahr., 546 F App'x 37 (2d Cir. 2013) (summary order), vacated on unrelated grounds sub. nom. St. Stephen's Sch. v. PricewaterhouseCoopers Accountants N.V., 570 F. Appx. 37 (2d Cir. 2014) (summary order). 
Revista Eletrônica de Direito Processual - REDP.

Rio de Janeiro. Ano 11. Volume 18. Número 1. Janeiro a Abril de 2017

Periódico Quadrimestral da Pós-Graduação Stricto Sensu em Direito Processual da UERJ

Patrono: José Carlos Barbosa Moreira. ISSN 1982-7636. pp. 68-122

www.redp.uerj.br

First, Part I will identify the filing of an essentially identical complaint back home by absentees from Latin America upon losing on the merits in the United States as the most likelythough still rather improbable - scenario in whicha Latin American adjudicator might confront the question whether to enforcethe judgment in a U.S. class action.It will attribute the relative likelihood to the practical impossibility of all other options andthe outweighing improbability to overarchingcivil-law impediments to this kind of litigation, as well as to the high chance of dismissal either forlack of jurisdiction or for expiration of the statute of limitations.In any event, the article will conclude that a judge from the region wouldalmost certainlyreject any such action in deference toultimate ruling by his or her colleague in the United States.

Part IIwillthereafterlistthe following as the main conditions for execution in Latin America:

(1) Reciprocity from the State of Origin

(2) Jurisdiction of the Foreign Court over the Matter

(3) Sufficiency of Service and Defense Opportunities

(4) Finality of the Judgment

(5) Absence of Any Pending Similar Domestic Suit

(6) Respect for Areas of Exclusive National Jurisdiction

(7) Compatibility with the Public Order

Part IIwill underscore the presumption in favor of enforcing decisions from abroad and then showthat the relevant legislation in Mexico, Brazil, Venezuela, Colombia, Panama, Peru, and Ecuador incorporates some or all of these criteria.

Next, Part IIIwill demonstratethat a definitive determination in a U.S. class action would meet the first six requirements. The various subdivisions of Part IV will, in turn, assertthat it would satisfy the seventh too.They will definethe concept of public order, which includes that of due process, and explainthat the U.S.judgmentwould cohere with both notions.Indeed, it would rest on a number of fairness controls designed for all class actionsand for those falling under Rule 23(b)(3). 
Revista Eletrônica de Direito Processual - REDP.

Rio de Janeiro. Ano 11. Volume 18. Número 1. Janeiro a Abril de 2017

Periódico Quadrimestral da Pós-Graduação Stricto Sensu em Direito Processual da UERJ

Patrono: José Carlos Barbosa Moreira. ISSN 1982-7636. pp. 68-122

www.redp.uerj.br

Accordingly, a Latin American judge would almost surely agree with the United States

Supreme Court that the opt-out regime fully comports with due process, ${ }^{5}$ especially since Latin America importedthisguaranty from the United States and preserved its central components intact.Moreover, he or she could point to any available local actions permitting, along the lines of Rule 23(b)(3), the aggregation of similar, interrelated individual claims of a large number of individuals, who acquiesce either by opting in rather informally or simply by failing to opt out.Furthermore, he or she could note that diffuse rights suits, which resemble Rule 23(b)(2) actions and exist throughout the continent, invariably bind absentees who have in no way consented or even received individual notice.As a whole, the discussion will stress that Latin American absent class members could not legitimately complain inasmuch as they would have free ridden on the efforts of their representatives with a chance at compensation, would have benefited from the aforementioned general and specific safeguards, and could have similarly faced preclusion in Latin America based on a suit prosecuted by someone else without their authorization.

In sum, the U.S. judiciary should, in principle, allow Latin Americans into class actions for economic compensation.Naturally, it should treat the presence of other "aliens" just as openly, conducting a comparative analysis analogous to that undertaken in this work.After all, achieving justice for all requires striving to includethe traditionally excluded.

\section{CONCRETE SCEnARIO}

This Partwill imagine aconcrete scenario in which an adjudicator in Latin Americamighthave to determine whether to recognize a final decision in a U.S. class action for damages.In the end, it willenvisage one in whicha Latin American absentclass member proceedsanew back home upon losing on the merits. The concluding paragraphs will acknowledge that such a situation is unlikely to materialize.Nonetheless, they will ultimately assertthat if itever didcome about, a tribunal in Latin America wouldalmost certainly opt for recognition.

Class action representatives suing for monetary compensation in the United States ordinarily do so under Federal Rule of Civil Procedure 23(b)(3). Hence, they mustdemonstrate not only "that the questions of law or fact common to class members predominate over any ques-

${ }^{5}$ Seeinfra Part IV(C). 
Revista Eletrônica de Direito Processual - REDP.

Rio de Janeiro. Ano 11. Volume 18. Número 1. Janeiro a Abril de 2017

Periódico Quadrimestral da Pós-Graduação Stricto Sensu em Direito Processual da UERJ

Patrono: José Carlos Barbosa Moreira. ISSN 1982-7636. pp. 68-122

www.redp.uerj.br

tions affecting only individual members" but also "that a class action is superior to other available methods for fairly and efficiently adjudicating the controversy." ${ }^{\circ}$ The provision itself lists as "pertinent to these findings ... the desirability or undesirability of concentrating the litigation of the claims in the particular forum."

The federal judiciarytends to view the presence of foreigners, along with the corresponding res judicata complications, as relevant tothe superiority inquiry, ${ }^{8}$ especially to theelement referred to in the last quotation. ${ }^{9}$ Presumably, it deems a class action incorporating such persons less desirable to the extent that they may litigate againin their nationsof origin upon a lossat trial and on appeal.From this perspective, the U.S. adjudicatormustfigure out whether judgesthere would defer tohis or herultimate ruling.

After examining the existingcase law, the United States Court for the Southern District of New York defined the standard in In re Vivendi:

Where plaintiffs are able to establish a probability that a foreign court will recognize the res judicata effect of a U.S. class action judgment, plaintiffs will have established this aspect of the superiority requirement. . . Where plaintiffs are unable to show that foreign court recognition is more likely than not, this factor weighs against a finding of superiority and, taken in consideration with other factors, may lead to the exclusion of foreign claimants from the class. ${ }^{10}$

Prior to ascertaining whether a tribunal abroad would honor their final decisions, however, federal judges should first ask themselves under what circumstances it might confront a request to do so.They could thus offer amore reliable prediction.

Upon a ruling favorable to them, Latin American plaintiffs or absenteeswill pretty definitely not pursueexecution in Latin America.Quite the opposite:they will undoubtedly demand

${ }^{6}$ FED. R. CIV. P. 23(b)(3).

${ }^{7}$ FED. R. CIV. P. 23(b)(3)(C).

${ }^{8}$ See, e.g., In re Vivendi Universal, 242 F.R.D. 76, 95 (S.D.N.Y. 2007) ("[R]es judicata concerns have been appropriately grafted onto the superiority inquiry."); Cromer Finance Limited v. Berger, 205 F.R.D. 113, 134 (S.D.N.Y. 2001) ("The res judicata effect of a class action judgment is a factor that must be considered in evaluating the superiority of the class action device.”).

${ }^{9}$ In discussing "the desirability or undesirability of concentrating the litigation of the claims in [the] particular forum," the Vivendi court started out by noting that the "Plaintiffs' proposed class definition encompasse[d] a significant number of foreign class members." In re Vivendi Universal, 242 F.R.D. at 92.

${ }^{10} \mathrm{Id}$. at 95 (internal quotations and citations omitted). 
Revista Eletrônica de Direito Processual - REDP.

Rio de Janeiro. Ano 11. Volume 18. Número 1. Janeiro a Abril de 2017

Periódico Quadrimestral da Pós-Graduação Stricto Sensu em Direito Processual da UERJ

Patrono: José Carlos Barbosa Moreira. ISSN 1982-7636. pp. 68-122

www.redp.uerj.br

compliance and, if necessary, seek enforcement in the United States.After all,a U.S. judge, in

contrast to his or her Latin American counterparts,enjoysbroad contempt powers, ${ }^{11}$ canreadily access the assets of defendants processed in the United States, and can enforce U.S. judgmentswithconsiderable efficiency.For similar reasons, the complainants' opponents will have little to gain from re-litigating thematterin Latin America.

If, instead, the adjudication ends updisfavoring the class, Latin Americanrepresentatives or represented membersof the class will probably not try to take another bite at the apple in Latin America.After all, they would run intogeneral and specific impedimentstoany such attempt. ${ }^{12}$ Generally, any suchrepeatlitigantwouldusuallyhave to(1)hire a lawyerona noncontingencybasis, ${ }^{13}(2)$ paytheattorney's fees of the other sideupon defeat, ${ }^{14}(3)$ rely on fact rather than noticepleading, ${ }^{15}(4)$ do without discovery, ${ }^{16}(5)$ meet a higher "deep-seated[]conviction,"in lieu of a more-likely-than-not, standard of proof, ${ }^{17}$ (6) present the evidence before a judge instead of a jury, ${ }^{18}$ and, as already suggested, (7) make do with judicial coercion mechanisms other than contempt. ${ }^{19}$ In particular, he or she would face an uphill battle against dismissaleither (1) for lack of jurisdiction, astypically the defendants resideand the

${ }^{11}$ SeeOQUENDO, Ángel R. Latin American Law. Minnesotta: West Academic, 2011, 2. ed., P. 64: (A civil law court, in contrast to its common-law counterpart, "does not have contempt powers to enforce its orders.").

${ }^{12} C f$., Anwar v. Fairfield Greenwich, Ltd., 289 F.R.D. 105, 120 (S.D.N.Y. 2013), partially aff'd sub. nom. Lomeli v. Sec. \& Inv. Co. Bahr., 546 F App'x 37 (2d Cir. 2013) (summary order), vacated on unrelated grounds sub. nom. St. Stephen's Sch. v. PricewaterhouseCoopers Accountants N.V., 570 F. Appx. 37 (2d Cir. 2014) (summary order) ("The Court ... takes into account the unlikely ability of plaintiffs from the relevant Latin American countries to bring a duplicative action in their home countries.").

${ }^{13}$ OQUENDO, Ángel R.Latin American Law, ob. cit., note 11, at 64 (Litigants "may not enter into a contingency fee agreement with their lawyer. They must therefore pay up front and hope for a victory on the merits in order to obtain a reimbursement....").

${ }^{14} I d$. ("The trial court also orders the defeated party to reimburse the other side's attorney's fees. Litigants must therefore keep in mind that if they lose, they will have to cover their adversary's litigation expenses, as well as their own.").

${ }^{15}$ See DODSON, Scott.Comparative Convergences in Pleading Standards. In: 158 U. PA. L. Rev. 441, 443 (2010). Disponível em http://repository.uchastings.edu/faculty_scholarship/1028, acesso em 25.04.2017: ("Unlike civil law countries, which require detailed fact pleading and often evidentiary support at the outset, ... Rule 8 requires only 'a short and plain statement of the claim showing that the pleader is entitled to relief,' a formula that has traditionally focused on notice rather than facts."').

${ }^{16}$ SeeOQUENDO, Ángel R. Latin American Law, ob. cit., note 11, at 62 ("The parties . . . do not have to go through a protracted ... discovery phase.").

${ }^{17}$ SeeCLERMONT, Kevin M.Standards of Proof Revisited. In:Vermont Law Review, vol. 33, no. 3 (Spring 2009). ("Instead of asking whether some fact $X$ (say, that the defendant executed the promissory note disputed in a noncriminal, or civil, lawsuit) is more likely true than not, the Civil Law asks whether the fact is so probable as to create an inner and deep-seated conviction of its truth.").

${ }^{18} \mathrm{SeeOQUENDO}$, Ángel R. Latin American Law. ob. cit., note 11, at 62 ("The parties . . . do not have to . . . prepare the case for jury trial. The judge decides both legal and factual issues.").

${ }^{19}$ See supra note 9 and accompanying text. 
Revista Eletrônica de Direito Processual - REDP.

Rio de Janeiro. Ano 11. Volume 18. Número 1. Janeiro a Abril de 2017

Periódico Quadrimestral da Pós-Graduação Stricto Sensu em Direito Processual da UERJ

Patrono: José Carlos Barbosa Moreira. ISSN 1982-7636. pp. 68-122

www.redp.uerj.br

alleged injury has taken placein the United States, or (2) because the statute of limitations has

expired after an expectedly protracted U.S. class suit, since someone whopurportsto repudiate the latter can hardly invoke it to stop the clock.

If any of the concerned Latin Americans insisted on lodging a complaint despite these disincentives, he or she would not, in all likelihood,survive a motion to dismiss, if not on the grounds just enumerated, then nearlycertainly for reasons ofres judicata, in deference to the ultimate ruling in the original litigation. Of course, the defendants would, in all probability,nottake theexonerationattained in the United States to Latin America forjudicial validation.On the contrary, they would, without much doubt,first sit on it: ready to interpose itagainst any effort by their adversaries to reignite the dispute.

The aforementionedobstaclesperhaps explain why barely anyone in Latin America seems to have tried to stakea claimpreviously rejected in the United States under Federal Rule of Civil Procedure 23 and why the judiciary of the region appears to haveseldomdealt with the issue of preclusion regarding U.S. class actions.In 2013, the U.S. District Court for the Southern District of New York observed, in Anwar v. Fairfield Greenwich, Ltd., that "the majority of Latin American courts have not specifically addressed the enforcement of United States class-action judgments. ${ }^{20}$ The observation remains true to this day and,apparently, an understatement.The research for this work has uncovered no opinion on point.

In any event, this article will maintain thatLatin American tribunalscould only arbitrarily refuse recognition and that they would almost surely not do so.Therefore, it will wind up agreeingwiththe finding in Anwar"that courts in ...Latin American countries would more likely than not recognize a class-action judgment" 21 andwill indeed assess the chances at muchgreater than fifty percent.Obviously, the judiciary in Latin America, as elsewhere, might actually engage in arbitrariness, whether due to incompetence or bias, and conduct itselfin a legally unpredictable manner.Nevertheless, it normally should not.

\footnotetext{
20289 F.R.D. 105, 120 (S.D.N.Y. 2013), partially aff'd sub. nom. Lomeli v. Sec. \& Inv. Co. Bahr., 546 F App’x 37 (2d Cir. 2013) (summary order), vacated on unrelated grounds sub. nom. St. Stephen's Sch. v. PricewaterhouseCoopers Accountants N.V., 570 F. Appx. 37 (2d Cir. 2014) (summary order).

${ }^{21} I d$. at 119-20. See also id. at 120 ("[It is] more likely than not that the courts of the various [Latin American] jurisdictions would recognize, enforce, and give preclusive effect to a judgment in this action.").
} 
Revista Eletrônica de Direito Processual - REDP.

Rio de Janeiro. Ano 11. Volume 18. Número 1. Janeiro a Abril de 2017

Periódico Quadrimestral da Pós-Graduação Stricto Sensu em Direito Processual da UERJ

Patrono: José Carlos Barbosa Moreira. ISSN 1982-7636. pp. 68-122

www.redp.uerj.br

Of course, the parties may end up securing the Court's approval under Rule 23(e) and set-

tling.If so, they could invoke the agreement in most Latin American jurisdictions, includingthe seven under examination, as a valid contract, ${ }^{22}$ or, in six ofthemas res judicata, ${ }^{23}$ against any subsequent suit.As a result, a settlement would operate as the functional equivalent of an adjudication.Accordingly, the discussion will exclusively focus on the latter, but will bear upon the former mutatis mutandis.

\section{RECOGNITION REQUIREMENTS}

The various Latin American countriesset comparable parameters for the recognition in their territory of a final judicial decision from abroad.They thus evince the influence of a regional and civil-lawlegislative and scholarly debate on the topic, ${ }^{24}$ of the 1928 Private International Law Convention, ${ }^{25}$ mainly drafted by Antonio Sánchez de Bustamante y Sirven, and of the 1979 Inter-American Convention on the Extraterritorial Validity of Foreign Judgments and Arbitral Awards. ${ }^{26}$ Each of the nations under examination provides a case in point. ${ }^{27}$

\footnotetext{
${ }^{22}$ SeeCD. Civ. (D.F.) (Mex.) (1928), art. 2944 ("La transacción es un contrato por el cual las partes haciéndose recíprocas concesiones, terminan una controversia presente o previenen una futura.”); CD. CIV. (Venez.) (1982), art. 1713 ("La transacción es un contrato por el cual las partes, mediante recíprocas concesiones, terminan un litigio pendiente o precaven un litigio eventual."); CD. CIV. (Colom.) (1887), art. 2469 ("La transacción es un contrato en que las partes terminan extrajudicialmente un litigio pendiente o precaven un litigio eventual.”); CD. CIV. (Para.) (1916), art. 1500 ("La transacción es un contrato por el cual las partes, dando, prometiendo o reteniendo cada una alguna cosa, evitan la provocación de un pleito o ponen término al que habían comenzado."); CD. CiV. (Peru) (1984), art. 1302 ("Por la transacción las partes, haciéndose concesiones recíprocas, deciden sobre algún asunto dudoso o litigioso, evitando el pleito que podría promoverse o finalizando el que está iniciado.”); CD. CIV. (Ecuad.) (2005), art. 2348 ("Transacción es un contrato en que las partes terminan extrajudicialmente un litigio pendiente, o precaven un litigio eventual.”).

${ }^{23}$ SeeCD. Civ. (D.F.) (Mex.) (1928), art. 2953 ("La transacción tiene, respecto de las partes, la misma eficacia y autoridad que la cosa juzgada. ...”); CD. CIV. (Braz.) (2002), art. 840 ("É lícito aos interessados prevenirem ou terminarem o litígio mediante concessões mútuas."); CD. CIV. (Venez.) (1982), art. 1718 ("La transacción tiene entre las partes la misma fuerza que la cosa juzgada."); CD. Pro. CiV. (Venez.) (1990), art. 255 ("La transacción tiene entre las partes la misma fuerza que la cosa juzgada."); CD. CiV. (Colom.) (1887), art. 2483 ("La transacción produce el efecto de cosa juzgada en última instancia. . . .”); CD. CIV. (PARA.) (1916), art. 1506 ("La transacción tiene para las partes la autoridad de la cosa juzgada."); CD. Civ. (Peru) (1984), art. 1302 ("La transacción tiene valor de cosa juzgada."); CD. CIV. (Ecuad.) (2005), art. 2362 ("La transacción surte el efecto de cosa juzgada en última instancia.").

24 There has been an "intense cross-fertilization of procedural ideas in the region."OQUENDO, Ángel R. Latin American Law. ob. cit., note 11, at 700. Seegenerallyid. at 5 ("[T] he various systems of law [in Latin America] resemble each other ... [due to] a shared history as well as . . . an intense process of cross-fertilization."); 114 ("In the realm of public law, Latin American countries [have] . . focused considerably on each other's law. European and North American influences often arrived via sister Iberian American nations. This intense cross-fertilization ... has continued to this day.”).

${ }^{25}$ See Convention on Private International Law (Bustamante Code), Feb. 20, 1928, 86 L.N.T.S. 111, O.A.S. T.S. No. 34.

${ }^{26}$ Inter-American Convention on Extraterritorial Validity of Foreign Judgments and Arbitral Awards, May 8, 1979, 1439 U.N.T.S. 91, O.A.S. T.S. No. 51.
} 
Revista Eletrônica de Direito Processual - REDP.

Rio de Janeiro. Ano 11. Volume 18. Número 1. Janeiro a Abril de 2017

Periódico Quadrimestral da Pós-Graduação Stricto Sensu em Direito Processual da UERJ

Patrono: José Carlos Barbosa Moreira. ISSN 1982-7636. pp. 68-122

www.redp.uerj.br

The relevantregimes applywhennospecial treaty exists, as with the United States in each instance, and invariablyrest on the presumption of enforcement.As a result, they compel a judge to enforceexcept upon failure to satisfy any of the followingconditions:

(1) Reciprocity from the State of Origin;

(2)Jurisdiction of the Foreign Court over the Matter;

(3) Sufficiency of Service and Defense Opportunities;

(4) Finality of the Judgment;

(5) Absence of Any Pending Similar Domestic Suit;

(6) Respect for Areas of Exclusive National Jurisdiction;

(7) Compatibility with the Public Order.

While these criteria may vary in their specific formulation from one country to the next, they all operate essentially identically, atleast for purposes of this work.In the interest of clarity, the discussion will adhere to the numberingabove, rather than that of the different legal systems.

Of course, the applicable schemewill usually requirecertain solemnities.For instance, it may demand the translation or authentication of the original decision. This article will not attend to these requirements.Assuming that the requesting party will have fulfilled them, it willzero in ontheaforementioned conditions.

First, Chapter VI of the Mexican Federal Code of Civil Procedure regulates the "Execution of Judgments." ${ }^{28}$ At the outset, Article 569 enunciates:"private, non-commercial, foreign judgments. . shall be enforced and recognized in Mexico so long as they do not run counter to the local public order." ${ }^{29}$ Hence, it presumes recognition, approaches public order as an exceptional ground of refusal, and, curiously, does not mention the other pre-requisites.Nonetheless,

27 "Generally, the relevant Latin American countries, regardless of whether they are signatories, look to the principles embodied in the Bustamante Code and Inter-American Convention on Extraterritorial Validity of Foreign Judgments and Arbitral Awards . . to determine whether to recognize a foreign judgment." Anwar v. Fairfield Greenwich, Ltd., 289 F.R.D. 105, 119 (S.D.N.Y. 2013), partially aff'd sub. nom. Lomeli v. Sec. \& Inv. Co. Bahr., 546 F App'x 37 (2d Cir. 2013) (summary order), vacated on unrelated grounds sub. nom. St. Stephen's Sch. v. PricewaterhouseCoopers Accountants N.V., 570 F. Appx. 37 (2d Cir. 2014) (summary order). ${ }^{28}$ CD. Fed. Pro. Civ. (Mex.) (1943), Lib. IV, Tít. I, Cap. VI, arts. 569-577 (“Ejecución de Sentencias”). Cf. CD. Pro. Civ. (D.F.) (Mex.) (1932), Tít. VII, Cap. VI ("De la Comparación Procesal Internacional”); CD. CoM. (Mex.) (1889), Lib. V, Tít. I, Cap. XXVII. (“Ejecución de Sentencias”).

${ }^{29}$ CD. Fed. Pro. Civ. (Mex.) (1943), art. 569 ("Las sentencias . . privad[a]s de carácter no comercial y . . . extranjer[a]s tendrán eficacia y serán reconocidos en la República en todo lo que no sea contrario al orden público."). 
Revista Eletrônica de Direito Processual - REDP.

Rio de Janeiro. Ano 11. Volume 18. Número 1. Janeiro a Abril de 2017

Periódico Quadrimestral da Pós-Graduação Stricto Sensu em Direito Processual da UERJ

Patrono: José Carlos Barbosa Moreira. ISSN 1982-7636. pp. 68-122

www.redp.uerj.br

the latter do appear subsequently in connection with the process of executing a decision from abroad and presumablygovernthat of solely recognizingit too.

In particular, Article 571 imposes "conditions"on the“execution" of a judgment.It embraces every single one of thoseinventoried above:

(1) "[T]he tribunal may deny execution upon proof that in the country of origin, foreign judgments . . . are not executed in analogous cases." ${ }^{\text {30 }}$

(2) "The judge or tribunal rendering the judgment must have had jurisdiction to consider and decide the matter under recognized international law rules that are compatible with those adopted by this Code." 31

(3) "The defendant must have been personally notified and served so as to assure his right to a hearing and tocarry out hisdefense." 32

(4) "[The judgment] must constitute res judicata in the country in which [it was] pronounced, with no further ordinary appealavailable."33

(5) "The original action maynot involve a matter presently pending before a Mexican tribunal in a dispute between the same parties." 34

(6) "[The judgment] may notstem from an in rem action.",35

(7) "The obligation enforced by the original action may not run counter to the public order in Mexico." $" 36$

Somewhat typically, this provision focuses onthe exclusive local jurisdictionover in rem suits.

Second, Brazil's 2015 Code of Civil Procedurefeatures a series of "indispensable requirements," ${ }^{37}$ including all of those previously numbered,with the exception of the first (1):

\footnotetext{
${ }^{30} I d$. art. 571 (“[E]l tribunal podrá negar la ejecución si se probara que en el país de origen no se ejecutan sentencias . . . extranjer[a]s en casos análogos.”).

${ }^{31} I d$. art. 571(III) ("Que el juez o tribunal sentenciador haya tenido competencia para conocer y juzgar el asunto de acuerdo con las reglas reconocidas en el derecho internacional que sean compatibles con las adoptadas por este Código[.]”).

${ }^{32} I d$. art. 571(IV) ("Que el demandado haya sido notificado o emplazado en forma personal a efecto de asegurarle la garantía de audiencia y el ejercicio de sus defensas[.]").

${ }^{33} I d$. art. 571(V) ("Que [la sentencia] tenga[] el carácter de cosa juzgada en el país en que fue[] dictad[a], o que no exista recurso ordinario en su contra[.]").

${ }^{34} I d$. art. 571(VI) ("Que la acción que les dio origen no sea materia de juicio que esté pendiente entre las mismas partes ante tribunales mexicanos[.]").

${ }^{35} I d$. art. 571(II) ("Que [la sentencia] no haya[] sido dictad[a] como consecuencia del ejercicio de una acción real[.]").

${ }^{36} I d$. art. 571(VII) ("Que la obligación para cuyo cumplimiento se haya procedido no sea contraria al orden público en México[.]”).
} 
Revista Eletrônica de Direito Processual - REDP.

Rio de Janeiro. Ano 11. Volume 18. Número 1. Janeiro a Abril de 2017

Periódico Quadrimestral da Pós-Graduação Stricto Sensu em Direito Processual da UERJ

Patrono: José Carlos Barbosa Moreira. ISSN 1982-7636. pp. 68-122

www.redp.uerj.br

(2) "[The foreign decision must have been] pronounced by an authority with jurisdiction." 38

(3) "[The decision,] even if ultimately entered by default, [must have been] preceded by a regular summons." 39

(4) "[The decision must] be effective in the country in which it was rendered," 40 as well as "definitive." 41

(5) "[The decision may] not run counter to Brazilian rulings with a res judicata effect." $" 42$

(6) "[The decision may not impinge upon the] exclusive jurisdiction of Brazil's judicial authorities." 43

(7) "[The decision may] not offend the public order."44

Article 26(2) makes clear that, in contrast to other instances of international legal cooperation, the recognition of a foreign judicial determination does not ride on the submission of a diplomatic statement confirming the existence of reciprocity. ${ }^{45}$ Moreover, Article 26(3) bans any such cooperation when it would breach "the Brazilian state's fundamental norms."46

Third, the 1998 Law of Private International Law controls this area in Venezuela. ${ }^{47} \mathrm{As}$ in Brazil, it sets forth among its "requirements"all of thoseoriginally enumerated but the first (1):

(2) "The tribunals issuing the judgmentsmust have jurisdiction over the cause of action. ..."48

${ }^{37}$ L. 13105, CD. Pro. Civ. (Braz.) (2015), art. 963 ("requisitos indispensáveis").

${ }^{38} I d$. art. 963(I) (“[A decisão deve ter sido] proferida por autoridade competente.”).

${ }^{39} I d$. art. 963(II) ("[A decisão deve ter sido] precedida de citação regular, ainda que verificada a revelia.").

${ }^{40} I d$. art. 963(III) ("[A decisão deve] ser eficaz no país em que foi proferida.”).

${ }^{41} I d$. art. 961(1).

${ }^{42} I d$. art. 963(IV) (“[A decisão deve ter sido] não ofender a coisa julgada brasileira.").

${ }^{43} I d$. art. 964 ("[A decisão não pode entrar em matéria de] competência exclusiva da autoridade judiciária brasileira.").

${ }^{44} I d$. art. 963(VI) (“[A decisão dever ter sido] proferida por autoridade competente.”).

${ }^{45} I d$. art. 26(2) ("Não se exigirá a reciprocidade [manifestada por via diplomática] para homologação de sentença estrangeira.").

${ }^{46} I d$. art. 26(3) ("Na cooperação jurídica internacional não será admitida a prática de atos que contrariem ou que produzam resultados incompatíveis com as normas fundamentais que regem o Estado brasileiro.”).

${ }^{47}$ L. DCHO. INT’L PRIV., Gaceta Oficial 36.511 (Venez.) (1998).

${ }^{48} I d$. art. 53(4) ("Que los tribunales del Estado sentenciador tengan jurisdicción para conocer de la causa. . ..). 
Revista Eletrônica de Direito Processual - REDP.

Rio de Janeiro. Ano 11. Volume 18. Número 1. Janeiro a Abril de 2017

Periódico Quadrimestral da Pós-Graduação Stricto Sensu em Direito Processual da UERJ

Patrono: José Carlos Barbosa Moreira. ISSN 1982-7636. pp. 68-122

www.redp.uerj.br

(3) "The defendant must have been duly served, must have had sufficient time to ap-

pear, and must have benefited from procedural guaranties that would reasonably al-

low him to build a defense." 49

(4) "The judgments must constitute res judicata according to the law of the state in which they were issued." 50

(5) "No lawsuit on the same matter, between the same parties, and initiated prior to the issuance of the foreign judgment may be pending before Venezuelan tribunals." ${ }^{51}$

(6) "The judgments may neither impinge upon real property rights pertaining to real estate located in Venezuela nor effectively deprive Venezuela of any exclusive jurisdiction it may have over the matter at stake." 52

(7) "Legal determinations based on. . foreign law ... shall produce effects in Venezuela, unless they contradict . . . the essential principles of the Venezuelan public order." 53

The first five items derive from several subparts of Article 53, which bears the heading "The Validity of Foreign Judgments." "The seventhand last one figures as the fifth of the "General Provisions" of Chapter I, ${ }^{55}$ recalling its Mexican analoguein its embrace of a presumptive implementation of foreign judicial decisions.

Fourth, Title XXXVI of Book Five of the Colombian Code of Civil Procedure deals with "Judgments . . Issued Abroad." "It contains among its "requirements"all of the formerly listed except the second (2):

\footnotetext{
${ }^{49} I d$. art. 53(5) ("Que el demandado haya sido debidamente citado, con tiempo suficiente para comparecer, y que se le hayan otorgado en general, las garantías procesales que aseguren una razonable posibilidad de defensa.").

${ }^{50} I d$. art. 53(2) ("Que tengan fuerza de cosa juzgada de acuerdo con la ley del Estado en el cual han sido pronunciadas.").

${ }^{51} I d$. art. 53(6) ("que no se encuentre pendiente, ante los tribunales venezolanos, un juicio sobre el mismo objeto y entre las mismas partes, iniciado antes que se hubiere dictado la sentencia extranjera.").

${ }^{52} I d$. art. 53(3) ("Que no versen sobre derechos reales respecto a bienes inmuebles situados en la República o que no se haya arrebatado a Venezuela la jurisdicción exclusiva que le correspondiere para conocer del negocio.”).

${ }^{53} I d$. art. 5 ("Las situaciones jurídicas creadas de conformidad con [el] Derecho extranjero . . . producirán efectos en la República, a no ser que contradigan . . . los principios esenciales del orden público venezolano.”). ${ }^{54} I d$. art. 53 ("De la Eficacia de las Sentencias Extranjeras").

${ }^{55}$ Id. Cap. I, arts. 1-10 ("Disposiciones Generales").

${ }^{56}$ CD. Pro. Civ. (Colom.) (1970), Lib. V, Tít. XXXVI, arts. 693-97 (“Sentencias . . Proferid[a]s en el Exterior”).
} 
Revista Eletrônica de Direito Processual - REDP.

Rio de Janeiro. Ano 11. Volume 18. Número 1. Janeiro a Abril de 2017

Periódico Quadrimestral da Pós-Graduação Stricto Sensu em Direito Processual da UERJ

Patrono: José Carlos Barbosa Moreira. ISSN 1982-7636. pp. 68-122

www.redp.uerj.br

(1) "Judgments pronounced in a foreign country ... shall have, [in the absence of a treaty,] the same force as that granted there to those issued in Colombia."57

(3) "[T[he defendant must have been duly served and afforded the opportunity to contest the charges, in accordance with the law of the state of origin,all of which is presumed by virtue of the finalityof the judgment." 58

(4) "The judgment must be final under the law of the country of origin. . .."59

(5) "There may be neither a pendingsuit nor a final judgment in Colombia on the same matter." 60

(6) "The judgment may not involve rights pertaining to real property located on Colombian territory. . .."61; nor any "matter over which Colombian judges have exclusive jurisdiction." 62

(7) "The judgment may not run counter to Colombian laws related to the public order." 63

Significantly, the provisiontakes a unique approach bystarting from the premise ofa suitable summons.

Fifth, Chapter III of Title VIII of the 2014 Panamanian Code of Private International Law governs "The Process of Recognition and Execution of Foreign Judgments." ${ }^{64}$ It posits, in its Article 179, a catalogue of "requirements"comprising all of those initially numerated with the exception of the fifth (5):

${ }^{57} I d$. art. 693 ("Las sentencias . . . pronunciadas en un país extranjero . . . tendrán, [de no haber un tratado,] la fuerza ... que allí se reconozca a las proferidas en Colombia.”).

${ }^{58} I d$. art. 694(6) ("Que ... se haya cumplido el requisito de la debida citación y contradicción del demandado, conforme a la ley del país de origen, lo que se presume por la ejecutoria.").

${ }^{59} I d$. art. 694(3) (“Que se encuentre ejecutoriada de conformidad con la ley del país de origen. ...”).

${ }^{60} I d$. art. 694(5) ("Que en Colombia no exista proceso en curso ni sentencia ejecutoriada . . sobre el mismo asunto.").

${ }^{61} I d$. art. 694(1) ("Que no verse sobre derechos reales constituidos en bienes que se encontraban en territorio colombiano. ...”).

${ }^{62} I d$. art. 694(4) ("Que el asunto sobre el cual recae, no sea de competencia exclusiva de los jueces colombianos.").

${ }^{63} I d$. art. 694(2) ("Que no se oponga a leyes u otras disposiciones colombianas de orden público. . ..”).

${ }^{64}$ L. 7, CD. DCho. InT’L PrIV. (Pan.) (2014), Tít. VIII, Cap. III ("Proceso de Reconocimiento y Ejecución de Sentencia Extranjera"). 
Revista Eletrônica de Direito Processual - REDP.

Rio de Janeiro. Ano 11. Volume 18. Número 1. Janeiro a Abril de 2017

Periódico Quadrimestral da Pós-Graduação Stricto Sensu em Direito Processual da UERJ

Patrono: José Carlos Barbosa Moreira. ISSN 1982-7636. pp. 68-122

www.redp.uerj.br

(1) "In the absence of a special treaty with the state of origin, the judgment maybe

executed,[e]xcept in case of proof that in that stateno compliance with the decisions

rendered by Panamanian tribunals takes place."65

(2) "The judgment must have been rendered by a tribunal with jurisdiction. . .."66

(3) "The defendant [must have been] personally served with the complaint.In other

words, the proceedings abroad must have allowed him to contest the charges."

(4) The "foreign judgment" must "constituteres judicata; it must be firm and final, as well as no longer subject to appeal."68

(6) “The judgment may notencroach upon the Panamanian judiciary's exclusive jurisdiction.Panamanian judges have exclusive jurisdiction over real estate located in Panama.",69

(7) "The judgment may not infringe upon fundamental principles or rights under the public order of Panama." 70

In Panama, in contradistinction to Colombia, the law apparently merely permits execution ifreciprocity exists.

Sixth, Title IV of Book X of Peru's 1984 Civil Code addresses the "Recognition and Execution of Foreign Judgments. . .."71To this end, Article 2104 catalogs seven "requirements," which mirror those proposed at the beginning of this comparative inquiry.

(1) "Reciprocity must be proven.",72

\footnotetext{
${ }^{65} I d$. art. 178 ("Si no hubiera tratados especiales con el Estado en el que se haya pronunciado la sentencia, esta podrá ser ejecutada, [s]alvo prueba de que en dicho Estado no se dé cumplimiento a las dictadas por tribunales panameños.”).

${ }^{66} I d$. art. 179 (1) ("Que la sentencia haya sido dictada por un tribunal competente. . . .").

${ }^{67} I d$. art. 179 (2): "Que . . la demanda . . haya sido personalmente notificada al demandado. Es decir, que el proceso evacuado en el extranjero haya cumplido con el principio del contradictorio.”).

${ }^{68} I d$. art. 179 (La "sentencia extranjera" debe estar "revestida de autoridad de cosa juzgada y . . . en el resorte de su jurisdicción . . . firme y no sujeta a recurso alguno.").

${ }^{69} I d$. art. 179 (1) ("Que la sentencia . . . no haya conculcado la competencia privativa de los tribunales panameños. Se entiende que la competencia sobre bienes inmuebles ubicados en la República de Panamá es de competencia privativa de los jueces panameños.").

${ }^{70} I d$. art. 179 (3) ("Que la sentencia pronunciada por tribunal extranjero no conculque principios o derechos fundamentales del orden público panameño.”).

${ }^{71}$ CD. CIV. (Peru) (1984), Lib. X, Tít. IV (“Reconocimiento y ejecución de sentencias . . extranjer[a]s.”).

${ }^{72}$ Id. art. 2104 (8) (“Que se pruebe la reciprocidad.”).
} 
Revista Eletrônica de Direito Processual - REDP.

Rio de Janeiro. Ano 11. Volume 18. Número 1. Janeiro a Abril de 2017

Periódico Quadrimestral da Pós-Graduação Stricto Sensu em Direito Processual da UERJ

Patrono: José Carlos Barbosa Moreira. ISSN 1982-7636. pp. 68-122

www.redp.uerj.br

(2)“The foreign tribunal must have had jurisdiction over the matter in accordance

with the rules of private international law and with general principles on internationalprocedural jurisdiction." 73

(3) "The defendant must have been served according to the law of the forum; had a reasonable amount of time to appear, and benefited from procedural guaranties to conduct his defense." 74

(4) "The judgment must constitute res judicataunder the law of the forum."75،The judgment may not clash with an earlier one that meets the requirements for recognition and execution established in this Title."76

(5) "There may be no trial pending in Peru between the same parties, on the same matter, and initiated prior to the lodging of the complaint from which the judgment ensued." 77

(6) "The judgment may notinvolve matters within Peru's exclusive jurisdiction."78

(7) "The judgment may not run counter to the public order or to good morals." "79

Echoing its Colombian counterpart, Article 2102 proclaims:"'In the absence of a treaty with the country in which the judgment was pronounced, the judgment shall have the same effect as that given there to judgments pronounced by Peruvian tribunals." ${ }^{\circ 0}$ Furthermore, under Article 2103:"If the judgment stems from a country that does not comply with the decisions of Peruvian tribunals, it shall have no force whatsoever in Peru. ${ }^{, 81}$ Nevertheless, Article 838 of the

\footnotetext{
${ }^{73} I d$. art. 2104 (2) ("Que el tribunal extranjero haya sido competente para conocer el asunto, de acuerdo a sus normas de Derecho Internacional Privado y a los principios generales de competencia procesal internacional.").

${ }^{74} I d$. art. 2104 (3) ("Que se haya citado al demandado conforme a la ley del lugar del proceso; que se le haya concedido plazo razonable para comparecer; y que se le hayan otorgado garantías procesales para defenderse.").

${ }^{75} I d$. art. 2104 (4) ("Que la sentencia tenga autoridad de cosa juzgada en el concepto de las leyes del lugar del proceso.").

${ }^{76} I d$. art. 2104 (6) ("Que no sea incompatible con otra sentencia que reúna los requisitos de reconocimiento y ejecución exigidos en este título y que haya sido dictada anteriormente.”).

${ }^{77} I d$. art. 2104 (5) ("Que no exista en el Perú juicio pendiente entre las mismas partes y sobre el mismo objeto, iniciado con anterioridad a la interposición de la demanda que originó la sentencia.”).

${ }^{78}$ Id. art. 2104 (1) ("Que no resuelvan sobre asuntos de competencia peruana exclusiva.”).

${ }^{79} I d$. art. 2104 (7) ("Que no sea contraria al orden público ni a las buenas costumbres.).

${ }^{80} \mathrm{Id}$. art. 2102 ("Si no hay tratado con el país en el que se pronunció la sentencia, tiene ésta la misma fuerza que en aquel país se da a las sentencias pronunciadas por los tribunales peruanos.”).

${ }^{81} \mathrm{Id}$. art. 2103 ("Si la sentencia procede de un país en el que no se da cumplimiento a los fallos de los tribunales peruanos, no tiene fuerza alguna en la República.”).
} 
Revista Eletrônica de Direito Processual - REDP.

Rio de Janeiro. Ano 11. Volume 18. Número 1. Janeiro a Abril de 2017

Periódico Quadrimestral da Pós-Graduação Stricto Sensu em Direito Processual da UERJ

Patrono: José Carlos Barbosa Moreira. ISSN 1982-7636. pp. 68-122

www.redp.uerj.br

Code of Civil Procedure declares:"The existence of reciprocity regarding the effect given abroad to judgments . . . pronounced in Peru shall be presumed. Whoever denies it shall bear the burden of negative proof." 82

Finally, Article 414 of Ecuador's Code of Civil Procedureannounces,likewise,that “foreign judgments. . . shall be complied with" even "[i]n the absence of international treaties and conventions," 83 basically treating compliance as the rule rather than the exception.It integratesonly three of the sevenrepeatedly invokedconditions (4, 6, and 7),expressly commanding the enforcement court to ascertain:

(4)"That the judgment constitutes res judicata under the laws of the country in which it was rendered." 84

(6) "That the judgment was rendered upon a personal cause of action.",85

(7) That the judgment does not "contravene public law or the laws of Ecuador." 86 The phrase "a personal cause of action"refers tosuitssounding in contract, tort, or the like, ${ }^{87}$ and thereby suggests the exclusion of those asserting real property claims. ${ }^{88}$ Moreover, the language quoted at the very end in (7) presumably meansthat the judgment may not collide with the notion of public order as reflected in Ecuadorian laws.

Thisarticle will nowexamine whethera decision in the case at hand would live up toall of the referenced prerequisites.Ultimately, it will conclude thatall of the jurisdictions under con-

${ }^{82}$ CD. PRo. Civ. (Peru) (1993), art. 838 ("Se presume que existe reciprocidad respecto a la fuerza que se da en el extranjero a las sentencias ... pronunciad[a]s en el Perú. Corresponde la prueba negativa a quien niegue la reciprocidad.").

${ }^{83}$ CD. Pro. Civ. (Ecuad.) (2005), art. 414 (“A falta de tratados y convenios internacionales, se cumplirán [las sentencias extranjeras].").

${ }^{84}$ Id. art. 414(a) ("Que la sentencia pasó en autoridad de cosa juzgada, conforme a las leyes del país en que hubiere sido expedida.”).

${ }^{85}$ Id. art. 414(b) ("Que la sentencia recayó sobre acción personal.").

${ }^{86}$ Id. art. 414 ("no contravenir al Derecho Público o a las leyes ecuatorianas").

${ }^{87}$ SeeBlack's Law Dictionary OnLineSEcond EdiTion. Disponível em:http://thelawdictionary.org/personalaction/, acesso em 18/02/17: "A personal action seeks to enforce an obligation imposed on the defendant by his contract or delict; that is, it is the contention that he is bound to transfer some dominion or to perform some service or to repair some loss.".

88 "Personal rights," according to the influential Chilean Civil Code, "are those that may only be vindicated against certain persons. . . .Personal actions derive from these rights." CD. Civ. (Chile) (1857), art. 578 ("Derechos personales . . . son los que sólo pueden reclamarse de ciertas personas. . . . De estos derechos nacen las acciones personales.”). See alsoCD. CIV. (Colom.) (1887), art. 666; CD. Civ. (Ecuad.) (2005), art. 596. "Real property rights," in contrast, "are those that we have over a thing, unrelated to any particular person. . . Real actions derive from these rights." CD. CIV. (Chile) (1857), art. 577 ("Derecho real es el que tenemos sobre una cosa sin respecto a determinada persona. . . . De estos derechos nacen las acciones reales.”). See alsoCD. Civ. (Colom.) (1887), art. 665; CD. Civ. (Ecuad.) (2005), art. 595. 
Revista Eletrônica de Direito Processual - REDP.

Rio de Janeiro. Ano 11. Volume 18. Número 1. Janeiro a Abril de 2017

Periódico Quadrimestral da Pós-Graduação Stricto Sensu em Direito Processual da UERJ

Patrono: José Carlos Barbosa Moreira. ISSN 1982-7636. pp. 68-122

www.redp.uerj.br

sideration would most likely opt for recognition.In fact, they could only arbitrarily hold otherwise.Once again, the judiciary in Latin America, just like anywhere else, might actually fall prey to such arbitrariness, whetherfor lack of competence or impartiality, and act legally unpredictably.Nonetheless, it normally shouldnot.

The analysiswill now turn concretely tothe first six of the seven standards referred to from the start.The subsequentand penultimate Part IV will concentrate on the seventh.In order to cover all of the underlying issues, it will break down into a number of sections.

\section{From RECIPROCITY TO RESPECT FOR \\ EXCLUSIVE LOCAL JURISDICTION}

This Part will start from the premise that the plaintiffs prosecute the original complaint in the federal judicial districtin which the main factsoccurred and in which some of the defendantsare domiciled. It will also assume acause of action for damages that does notinvolve realproperty located in Latin America. Likewise, the discussion willrest on the final assumption that the judge adjudicates on the basis of diversity of citizenship under the law of a state that has adopted the 2005 Uniform Foreign-Country Money Judgment Recognition Act. ${ }^{89}$

First, Mexico, Colombia, Panama and Peru, which openly require reciprocity, should ordinarily concede that itexists.So should the remaining nations, insofar as they might incorporate the same requirementsub silentio.After all, the just cited Uniform Actestablishes that tribunals "shall recognize" judicial decisions from abroad. ${ }^{90}$ Quite predictably and consistently with its Latin American equivalents, it carves out exceptions when, inter alia, the legal system of origin lacks impartiality or "due process," 11 "the foreign court did not have personal jurisdiction over the defendant" notice of the proceeding in sufficient time to defend," "94"the judgment was obtained by fraud," $" 95$ "the judgment or the [[original] cause of action] is repugnant to the [local] public pol-

${ }^{89}$ Unif. Foreign-Country Money Judgments Recognition ACt (Unif. Law Comm'n 2005).

${ }^{90} I d$. $\$ 4(\mathrm{a})$.

${ }^{91} I d . \S 4(b)(1)$.

${ }^{92} I d . \S 4(\mathrm{~b})(2)$.

${ }^{93} I d . \S 4(b)(3)$.

${ }^{94} I d . \S 4(\mathrm{c})(1)$.

${ }^{95} I d . \S 4(\mathrm{c})(2)$. 
Revista Eletrônica de Direito Processual - REDP.

Rio de Janeiro. Ano 11. Volume 18. Número 1. Janeiro a Abril de 2017

Periódico Quadrimestral da Pós-Graduação Stricto Sensu em Direito Processual da UERJ

Patrono: José Carlos Barbosa Moreira. ISSN 1982-7636. pp. 68-122

www.redp.uerj.br

icy,"96 or "the judgment conflicts with another final and conclusive judgment"

when the foreign forum failsto recognize local judicial rulings." A party resisting recognition

of a foreign-country judgment," per Section 4(d), "has the burden of establishing that a ground for nonrecognition ... exists." $" 98$

Second, the U.S. District Courtwould enjoythe requisite jurisdictional power over the subjectmatterunder the law ofMexico, Brazil, Venezuela, Panama, and Peru, as well as ofany other nation that might impose this pre-requisite by implication. "The judge or tribunal rendering the judgment," according to Mexico's Federal Code of Civil Procedure, “must have had jurisdiction to consider and decide the matter under recognized international law rules that are compatible with those adopted by this Code." ${ }^{99}$ Indeed, the latter, like the former,should allow theassertion of jurisdiction in the United States.In particular, they accord jurisdictional authority to the tribunal"of the defendant's domicile" in "personal actions," 100 e.g., those sounding in contracts or torts, as well asto the tribunal"located in the place where fulfillment of the obligation was agreed upon to take place." ${ }^{101}$ The federal judgewould therefore possess jurisdiction inasmuch as he or sheholds courtin the state of domicile of at least one of the defendants, ${ }^{102}$ as well as to the degree that there might have been an agreement to fulfill any related duties there.

The Brazilian Code of Civil Procedure, somewhat like its Mexican counterpart, reads: "An action based on a personal right or on a right to personal property shall be instituted in the forum of the defendant's domicile." ${ }^{103}$ Once again, the U.S. adjudicator would have jurisdic-

\footnotetext{
${ }^{96}$ Id. $\S 4(\mathrm{c})(3)$.

${ }^{97} I d . \S 4(\mathrm{c})(4)$.

${ }^{98} \operatorname{Id} . \S 4(\mathrm{~d})$.

${ }^{99}$ CD. FED. PRo. Civ. (Mex.) (1943), art. 571(III) ("Que el juez o tribunal sentenciador haya tenido competencia para conocer y juzgar el asunto de acuerdo con las reglas reconocidas en el derecho internacional que sean compatibles con las adoptadas por este Código.”).

${ }^{100}$ Id. art. 24(IV) ("El del domicilio del demandado, tratándose de acciones reales sobre muebles o de acciones personales, colectivas o del estado civil.”). See supra notes 85-86 and accompanying text.

${ }^{101}$ CD. Fed. Pro. Civ. (Mex.) (1943), art. 24(II) ("El del lugar convenido para el cumplimiento de la obligación.").

102 "If there were various defendants with different domiciles, the judge sitting in the domicile chosen by the plaintiff shall have jurisdiction.” CD. PRo. CIV. (D.F.) (Mex.) (1932), art. 156(IV) (“Cuando sean varios los demandados y tuvieren diversos domicilios, será competente el juez que se encuentre en turno del domicilio que escoja el actor.”).

${ }^{103}$ CD. PRO. Civ. (Braz.) (2015), art. 46 ("A ação fundada em direito pessoal ou em direito real sobre bens móveis será proposta, em regra, no foro de domicílio do réu.”).
} 
Revista Eletrônica de Direito Processual - REDP.

Rio de Janeiro. Ano 11. Volume 18. Número 1. Janeiro a Abril de 2017

Periódico Quadrimestral da Pós-Graduação Stricto Sensu em Direito Processual da UERJ

Patrono: José Carlos Barbosa Moreira. ISSN 1982-7636. pp. 68-122

www.redp.uerj.br

tion under this standard because some of the defending partiesare domiciled in the state of the seat of her court.

Furthermore, Venezuela and Panama have legislated separately on private international law, defining specialized jurisdictional norms in thisfield.For instance, Articles 40 and 47of the Venezuelan 1998 Law of Private International Lawjurisdictionally empowerthe tribunals of the "territory" where the "facts"happened, where the "obligations were to be carried out,"or where the "contracts" wereexecuted. ${ }^{104}$ Similarly, Chapter V of the Preliminary Title ofthe Panamanian2014 Code of Private International Law bearsthe caption"Forum of Judicial Jurisdiction." ${ }^{105}$ In Article 13, it confers "jurisdiction"in "torts"upon "tribunals. . . where the harm occurred";"in personal actions" upon those "of the defendant's domicile"; and otherwise upon those "where the defendant's goods and assets are located." ${ }^{\text {"In }}$ In Peru, for its part, the 1984 Civil Code's Title IV, captioned“Recognition and Execution of Foreign Judgments . . ., ${ }^{107}$ solely invokes, under Article 2104(2), international legal norms:“The foreign tribunal must have had jurisdiction over the matter in accordance with its rules of private international law and general principles on international jurisdiction." $" 108$

The U.S. district courtwouldbe able to exercise its jurisdictional power under these international criteria.It sits where many of the relevant allegedactionstranspired and where at least one of the defendants is domiciled, if not where some of defendants'resources are located and where some of the averred obligations should have been performed.Moreover, the judge will rule on the merits possibly uponconcluding, for purposes of venue under 28 U.S.C. $\S$ 1391(b)(2), that"a substantial part of the events or omissions giving rise to the claim occurred, or a substantial part of property that is the subject of the action is situated" in her"judicial district." ${ }^{109}$ Finally, theapplication ofstate lawwillride on a determination that the "State [has] a

${ }^{104}$ L. DCho. InT'L Priv., Gaceta Oficial 36.511 (Venez.) (1998), arts. 40, 47.

105 L. 7, CD. DCho. InT’L Priv. (Pan.) (2014), Tít. Prelim., Cap. V (“Foro de Competencia Judicial”).

${ }^{106}$ Id. art. 13.

${ }^{107}$ CD. CIV. (Peru) (1984), Lib. X, Tít. IV (“Reconocimiento y ejecución de sentencias . . extranjer[a]s.”).

${ }^{108}$ Id. art. 2104 (2) ("Que el tribunal extranjero haya sido competente para conocer el asunto, de acuerdo a sus normas de Derecho Internacional Privado y a los principios generales de competencia procesal internacional.").

10928 U.S.C. $§ 1391(b)(2)(2012)$. 
Revista Eletrônica de Direito Processual - REDP.

Rio de Janeiro. Ano 11. Volume 18. Número 1. Janeiro a Abril de 2017

Periódico Quadrimestral da Pós-Graduação Stricto Sensu em Direito Processual da UERJ

Patrono: José Carlos Barbosa Moreira. ISSN 1982-7636. pp. 68-122

www.redp.uerj.br

significant contact or significant aggregation of contacts, creating state interests, such that choice of its law is neither arbitrary nor fundamentally unfair.""110

As to the third parameter, the summonsand the trial as a whole willunfold under the Federal Rules of Civil Procedure.Consequently, theywillafford each defendantsuitable serviceand occasionvigorously to defenditself,as expressly mandatedinMexico, Brazil, Venezuela, Colombia, Panama, and Peru and as might be expected elsewhere.Obviously, none of the analyzed schemescalls, with respect to other persons, for any kind of notificationor a corresponding opportunity to litigate effectively, let alone a full-fledged summons. ${ }^{111}$ All the same, by virtue of Rules 23(c)(2)(B), 23(d)(1)(B)(iii), and 24, absent class members willreceive individual notice and have a chance to participate in the litigation. ${ }^{112}$ As shown in Sections IV(B) and (C), they willbenefit overall from a series of safeguardsthat completely comport with due process, as construed in Latin America, as well as in the United States.

Fourth, the ultimate decision will possess finality and amount to res judicata under U.S. law, as prescribed by all of the Latin American regimes under consideration.Ex hypothesis, the federal judiciary willfinally decidethe controversy, with no possibility of further appeal, by the time a tribunal south of the border confrontsthe requestfor recognition.Besides, the judgment will constitute res judicata in the terms spelled out by the Supreme Court of the United States:

There is of course no dispute that under elementary principles of prior adjudication a judgment in a properly entertained class action is binding on class members in any subsequent litigation .... Basic principles of res judicata (merger and bar or claim preclusion) . . . apply.A judgment in favor of the plaintiff class extinguishes their claim, which merges into the judgment granting relief.A judgment in favor of the defendant extinguishes the claim, barring a subsequent action on that claim. ${ }^{113}$

Hence, the judgment will preclude all parties and all absentees.

Fifth, the inquiry at stakeequallypresupposes the absenceof any pending similar domestic suit, as explicitly demanded in Mexico, Brazil, Venezuela, Colombia, and Peru and as perhaps implicitly necessitated in other nations.It zeroes in on the very first Latin American complaint,

\footnotetext{
${ }^{110}$ Allstate Insurance Co. v. Hague, 449 U.S. 302, 313 (1981).

${ }^{111}$ Seeinfra Section IV(D).

112FED. R. CIV. P. 23(c)(2)(B), 23(d)(1)(B)(iii), 24.

${ }^{113}$ Cooper v. Fed. Reserve Bank of Richmond,467 U.S. 867, 874 (1984).
} 
Revista Eletrônica de Direito Processual - REDP.

Rio de Janeiro. Ano 11. Volume 18. Número 1. Janeiro a Abril de 2017

Periódico Quadrimestral da Pós-Graduação Stricto Sensu em Direito Processual da UERJ

Patrono: José Carlos Barbosa Moreira. ISSN 1982-7636. pp. 68-122

www.redp.uerj.br

which as such would precede any competing attempts.As to the sixth standard, which all of the concerned countries embrace, the underlying controversy, as described,does nottouchupon real estate located in Latin America and presumably does notimpingeupon any local jurisdictional prerogatives.

\section{Public Order}

\section{A. Definition AND OVERVIEW}

Latin American jurisdictions, including all sevenfocused on in this article,invariably permit a tribunaltorefuse to uphold a final judicial decisionfrom abroad that runs counter to the public order.Obviously, they do not thus purport to eradicateor underminethe presumption in favor of recognition.The exception in question applies only if the judgment at stakeclearly collides with vital precepts of the national legal system and polity. ${ }^{114}$

Drawing on the work of French scholar Henri Capitant, the Supreme Court of Panamahas defined the public orderin these terms: "[T] he public order encompasses norms and principles that advance the interests of individuals and guarantee societal coexistence. It contributes to social and collective welfare guided by the precepts of justice and morality that should prevail in every nation. It finds expression in the fundamental principles enshrined in our Constitution." ${ }^{115}$ In other words, this notion comprises a series of shared normative convictions that relate to the well-being of the people, individually and collectively, and that ordinarily take constitutional form.

Consequently, the public order does not amount merely to the laws currently in force.Nor does it boil down to official policy, which may stem from an isolated or tentative determination by one of the branches of government. The public order sets itself apart precisely because

\footnotetext{
${ }^{114}$ Cf. Anwar v. Fairfield Greenwich, Ltd., 289 F.R.D. 105, 115 (S.D.N.Y. 2013), partially aff'd sub. nom. Lomeli v. Sec. \& Inv. Co. Bahr., 546 F App'x 37 (2d Cir. 2013) (summary order), vacated on unrelated grounds sub. nom. St. Stephen's Sch. v. PricewaterhouseCoopers Accountants N.V., 570 F. Appx. 37 (2d Cir. 2014 ) (summary order) ("Therefore, the Court concludes that, where a plaintiff sufficiently demonstrates that the stated policy of a foreign country is to recognize and enforce foreign judgments, or that its law is generally inclined to favor that course of action, such a showing would create a rebuttable presumption that, absent an affirmative showing to the contrary, recognition of a particular United States judgment, even in class action litigation, does not violate a foreign country's public policy.”).

115 [Grupo Capital Factoring v. Karikal Investment], Exp. No. 852-02(Sala 4ta Negocios Generales) (Ct. Supr.) (Pan.) (2008) ("[E]l orden público comprende las normas y principios que defiende los intereses de los particulares y que garantiza la convivencia en sociedad, busca la seguridad social y colectiva, donde se destacan los principios de justicia y moral que deben regir en todo Estado; además de concebirse como los principios fundamentales estipulados en nuestra constitución.”).
} 
Revista Eletrônica de Direito Processual - REDP.

Rio de Janeiro. Ano 11. Volume 18. Número 1. Janeiro a Abril de 2017

Periódico Quadrimestral da Pós-Graduação Stricto Sensu em Direito Processual da UERJ

Patrono: José Carlos Barbosa Moreira. ISSN 1982-7636. pp. 68-122

www.redp.uerj.br

it usually develops over time, under the influence of numerous institutions, and impinges upon communal life as a totality in a relatively permanent manner.

Of course, the statutes and policies in force may coincide with or reflect the public order.They often do not,though.Hence, one must check for further corroboration in organic, constitutional, judicial, jurisprudential, and international sources.For example, a judge in an extradition proceeding mayhave to assess a foreign death penaltyfor consistency with the public order. ${ }^{116} \mathrm{He}$ or she may start by observing that the national penal code does not provide for thecapital sentenceand that the current administration has, as a matter of policy, opposed an amendment.Nonetheless, the adjudicator would normally also examine the local bill of rights, ratified international treaties, and so forth in order to look fortherequisitedenunciation-rather categorical and definitive - of this sort of punishment.

In this sense, the Mexican Supreme Court has declared:

The public order takes the law and the case law into account and ultimatelyconstitutes a norm thathas a nullifying effect under extreme circumstances.It does not rest on a sum of purely private interests.It touches upon interests of such an importancethat it ends up forbidding acts thatmay harm the collectivity, the state, or the nation, even if the concerned parties suffer no loss and actually acquiesce. ${ }^{117}$

From this standpoint, a foreignjudgment must clash with these crucial interests, or with the previously invoked fundamental principles, and injure the entire societyin order to be incompatible with the public order.

A final decision in a class action would presumablycomply with U.S. lawon substance and procedure and, therefore, with almost any conceivable cardinal norm in Latin America.All the same, it might raise due process concernsbecause of the way in which it would preclude absent class members.More concretely, Latin American absentees seeking a second bite at the

\footnotetext{
116 In Argentina, for example, extradition will not "lie whenever it would run counter to . . the public order." L. 24767 (Arg.) (1998), art. 10 (No "procederá la extradición cuando existan especiales razones de . . orden público[.]").

117 Seman. Jud. Fed., 3ra Sala, 5ta Época,T. XXXVII, 1835 (Supr. Ct.) (Mex.) (1933) ("El orden público que tiene en cuenta la ley y la jurisprudencia, para establecer una norma sobre las nulidades radicales, no puede estar constituido por una suma de intereses meramente privados; para que el orden público esté interesado, es preciso que los intereses de que se trate, sean de tal manera importantes, que, no obstante el ningún perjuicio y aun la aquiescencia del interesado, el acto prohibido pueda causar un daño a la colectividad, al Estado o a la nación.”).
} 
Revista Eletrônica de Direito Processual - REDP.

Rio de Janeiro. Ano 11. Volume 18. Número 1. Janeiro a Abril de 2017

Periódico Quadrimestral da Pós-Graduação Stricto Sensu em Direito Processual da UERJ

Patrono: José Carlos Barbosa Moreira. ISSN 1982-7636. pp. 68-122

www.redp.uerj.br

apple back home might protest that they never explicitly agreed to the suit, let alone to its res

judicata consequences.

The concept of due process, together with its strict ban on legally arbitrary deprivations of

life, liberty, or property, has become a central component of the constitution and the public order everywhere in Latin America. ${ }^{118}$ Significantly, ittraveledfrom the United States southward, starting in the nineteenth century, and eventually reachedevery cornerof this vast territory. ${ }^{119} \mathrm{As}$ a result, the inquiry into whether the preclusion, underRule $23(\mathrm{c})(3)(\mathrm{B})$, of a person who has not affirmatively consented to the complaint contravenes due process would not unfold much differently north and south of the border.

In all likelihood, a tribunal in Latin America, as in the United States, would essentially passon the fairness of the procedural setupvis-à-vis absent class members. ${ }^{120}$ It wouldprobably

\footnotetext{
${ }^{118}$ See generallyOQUENDO,Ángel R. Latin American Law. ob. cit., note 11, at 351 ("Since the attainment of independence in the nineteenth century, Latin American constitutions have guaranteed . . due process.").

${ }^{119}$ See, e.g., id. at 746 ("Article 14 [of the Mexican Federal Constitution] enunciates various guaranties that echo U.S. constitutional principles such as the ban on ex post facto laws and due process."), 289 (“Articles 14 and 16 [of the Mexican Federal Constitution] echo the due process clauses of the U.S. Constitution's fifth and fourteenth amendments."), 789 (“Constitution (Brazil) (1988), Title II (Fundamental Rights and Guarantees), Chapter I (Individual and Collective Rights and Duties), Article 5(LIV): 'No one shall be deprived of his or her liberty or assets without due process of law."). The District Court on Civil and Labor Matters for the State of Nuevo Leon in Mexico has observed that "the notion of due process of law, which has its origins in Anglo-Saxon law, was exported to Mexico" and that, in this respect, "the United States and Mexico honor the same principle." Exp. Jud. 32/9009-II, 22-23 (Juzg. 1ro Dist. Mat. Civ. \& Tbjo.)(Nuevo León) (Mex.) (2010) (“[E]l debido proceso legal cuyo origen es el derecho anglosajón . . . se exportó a México.”) (“[E]n Estados Unidos de América como en México se consagra el mismo principio.”).

${ }^{120}$ Seegenerallyid., at 746-68, 789-96 (Ch. XII, §§ C, E) (Due Process Case Law in Mexico and Brazil). Latin American tribunals, like their U.S. counterparts, essentially assess whether existing procedures treat concerned individuals fairly. In Melgar Castillejos v. President, for example, the Mexican Supreme Court held that the preliminary internment of a person for mental incompetence without a hearing violates due process. It declared: "We conclude that the challenged statute could lead to confinement and appointment of a tutor when the person concerned is in full possession of all of his or her capacities. The statutory provisions clearly deny him or her the opportunity to make allegations or introduce evidence to establish his or her lucidity, for they do not entitle him or her to intervene in the process." Id. at 752-53. In Brazilian Union of Composers v. Villarinho, Brazil's Supreme Court reasoned along parallel lines when it struck down an organization's decision to throw out a member without allowing him to respond: "[The complainant's] expulsion . . without guaranteeing him an ample defense, cross-examination, and constitutional due process disadvantages him considerably. He can no longer exercise the copyright related to the performance of his works. Moreover, even if plaintiff had joined other similar entities, at the national or international level, the imminent disciplinary exclusion would burden him. . ." Id. at 792. Precisely in an execution proceeding, the District Court on Civil and Labor Matters for the State of Nuevo Leon in Mexico took an analogous approach in rejecting the defendant's objection to the service of process under Texas law. It stated: "This tribunal cannot question the particular mechanisms available [in the United States] to enforce the right to a hearing ... for one cannot expect the summons in that nation to comport with Mexican law, only that it assure the defendant the right to fair treatment.” Exp. Jud. 32/9009-II (Juzg. 1ro Dist. Mat. Civ. \& Tbjo.)(Nuevo León) (Mex.) (2010), 23 ("este juzgado no puede cuestionar los mecanismos [estadounidenses] para hacer efectiva la garantía de au-
} 
Revista Eletrônica de Direito Processual - REDP.

Rio de Janeiro. Ano 11. Volume 18. Número 1. Janeiro a Abril de 2017

Periódico Quadrimestral da Pós-Graduação Stricto Sensu em Direito Processual da UERJ

Patrono: José Carlos Barbosa Moreira. ISSN 1982-7636. pp. 68-122

www.redp.uerj.br

probe:(1) into the extent to which they had their interests appropriately protected in the proceedings, through their representative, their class attorney, and the trial judge,(2) into the sufficiency of the notice they received, and(3) into whether they had a realpossibility ofpreserving their right to a day in court. The next two Sections will deal with these mattersin relationto class actions in general and to those specifically controlled by Rule 23(b)(3), respectively.

Furthermore, a Latin American judge would almost certainlyconsidercomparable homegrown suits.He or she would determine whether theyshare those features of Rule 23(b)(3) actions alleged to infringe upon due process.Section E will first discuss regional suitsthat operate analogously in that they allow the vindication of a large number of similar, interrelated individual entitlements, so-called "homogenous individual rights."In the end, they instantly bind scores of people, who have assented to the litigationeither by opting in, rather informally, or simply by failing to opt out.In consequence, the U.S. opt-out scheme will,in all probability, not come across as unfair even in jurisdictions that require represented persons somehow to opt in.

Finally, Subsection E(3) will analyze diffuse rights suits, which resemble Rule 23(b)(2) actions or citizen suits and which exist in every single one of the nations under consideration, as well as all over the continent.It will expose them aswresting the individual right to suefrom an absenteewithout securing any kind of consentfrom him or her, without affording him or herpersonal notification, and without according him or her an opportunityto bail out.Upon stressing the irrelevance of the fact that the underlying substantive entitlement is collective instead of individual, the analysis will close with the assertion that Latin American tribunals wouldalmost surelyadjudge Rule 23(b)(3) actions, as well as these ubiquitous diffuse rights suits, consistent with due process and the public order.

As a whole, the ensuing segments of this Part willendorse the holding inAnwar v. Fairfield Greenwich, Ltd., that an adjudicator in Latin Americawould not deem a "judgment [in a Rule 23(b)(3) action] manifestly contrary to the . . public [order]." ${ }^{121}$ Nevertheless, they willprogressfrom noting "the absence ... of any authority from the relevant Latin American coun-

diencia; ... . por lo que es imposible pretender que el emplazamiento en esa nación sea conforme a la legislación mexicana; lo relevante es que se asegure al demandado la garantía de trato.”).

121289 F.R.D. 105, 119 (S.D.N.Y. 2013), partially aff'd sub. nom.Lomeli v. Sec. \& Inv. Co. Bahr., 546 F App'x 37 (2d Cir. 2013) (summary order), vacated on unrelated grounds sub. nom. St. Stephen's Sch. v. PricewaterhouseCoopers Accountants N.V., 570 F. Appx. 37 (2d Cir. 2014) (summary order). 
Revista Eletrônica de Direito Processual - REDP.

Rio de Janeiro. Ano 11. Volume 18. Número 1. Janeiro a Abril de 2017

Periódico Quadrimestral da Pós-Graduação Stricto Sensu em Direito Processual da UERJ

Patrono: José Carlos Barbosa Moreira. ISSN 1982-7636. pp. 68-122

www.redp.uerj.br

tries expressly stating that the enforcement of a United States opt-out class action judgment would manifestly violate the public [order]"122 to demonstrating,along the lines just delineated, that an order to enforce would indeedcohere with the public order.That is to say, a judge in Latin America wouldnot onlypresumebut alsoascertainsuch coherence.

Moreover,a Latin American tribunalwould most likely realize that a refusal to recognize the ultimate U.S. judicial ruling would, in practice, deprivedefendantsthemselvesof due process, as well as discriminate against them.In particular, they would have riskedeffective liability toabsent class members from Latin America without really attaining a corresponding, complete exoneration upon a victory on the merits.Finally, these absentees, irrespective of whether they had ever lived in or even visited the United States, could not rightfully denouncethe preclusive impact on them.After all, they would have had ashot at compensationthrough the effort of others, would have benefited from a panoply ofprocedural protections, along withthe right to ample information and to exit, and could have basically faced the same sweeping res judicata effect in their lands of origin.

\section{B. Due Process and Class Action Absentees}

On first impression, any judgment arrived at in the present controversy might seem to encroach upon due process insofar as it binds absent class members who reside in Latin America, who did not appear as plaintiffs, and who merely failed to "opt out."These claimants might contend that they never really consented to this collective suit, let alone participated in it, and that they shouldpreserve the rightto re-litigate their claims upon a defeat on the merits.

Class actions exist preciselyfor the sake and advantage of the represented persons.Not surprisingly, the drafters and the judicial interpreters of Rule 23 havepainstakingly sought to secure the entitlements of absentees.Moreover, they have done so based onthe same due process concept thatLatin American jurisdictions have adopted. While this process of adoption has entailed some adaptation and modification, it has not led to an alteration of the basic tenets, through which U.S. law has developed thislitigation device. ${ }^{123}$ Therefore, a judge in Latin America should deem theU.S. class actionitself and the final decisionto be compatible with the local conception of due process.

${ }^{122} I d$. at 120 .

${ }^{123}$ SeegenerallyOQUENDoÁngel R. Latin American Law. ob. cit., note 11, at 730-96(Ch. XII). 
Revista Eletrônica de Direito Processual - REDP.

Rio de Janeiro. Ano 11. Volume 18. Número 1. Janeiro a Abril de 2017

Periódico Quadrimestral da Pós-Graduação Stricto Sensu em Direito Processual da UERJ

Patrono: José Carlos Barbosa Moreira. ISSN 1982-7636. pp. 68-122

www.redp.uerj.br

Significantly, the Advisory Committee on the 1966 Amendment, which produced, in essence, the currently enforced Rule $23,{ }^{124}$ viewed its mission as treating fairly, or consistently with due process, ${ }^{125}$ the totalityof class memberssubject topreclusion by virtue ofthe ultimate ruling.It perceived as a main deficiency of the original version the failure to "provide an adequate guide to the proper extent of the judgments in class actions" and to "address . . the question of the measures that might be taken during the course of the action to assure procedural fairness. ..."126In response, the end product:

provides that all class actions maintained to the end as such will result in judgments including those whom the court finds to be members of the class, whether or not the judgment is favorable to the class[,] and refers to the measures which can be taken to assure the fair conduct of these actions. ${ }^{127}$

Naturally, because the representatives appear themselves before the judge, issues of fairness arise mostly with respect to represented class members. The Supreme Court has interpreted many of the "specifications of the Rule [as] designed to protect absentees by blocking unwarranted or overbroad class definitions." ${ }^{128}$ In this sense, it has held that the prerequisites established in subsections (a) and (b) not only "focus court attention on whether a proposed class has sufficient unity so that absent members can fairly be bound by decisions of class representatives," but also, more generally, aim at "the protection of absent class members [and] serve to inhibit appraisals of the chancellor's foot kind. ..."129

Indeed, Rule 23 structures the whole procedure for class actions with an eye to ensuring the fair treatment ofevery class member.For instance, it does not permit the plaintiffs simply to lodge a complaint and proceed, butrathercommandsthemto certify the class beforehand.In par-

\footnotetext{
124 Ortiz v. Fibreboard, 527 U.S. 815, 833 (1999) (“[M]odern class action practice emerged in the 1966 revision of Rule 23.”); Amchem v. Windsor, 521 U.S. 591, 613 (1997) ("Rule 23, governing federal-court class actions, stems from equity practice and gained its current shape in an innovative 1966 revision.”).

125 Clark v. Arizona, 548 U.S. 735, 771 (2006) ("[D]ue process requires" "the standard of fundamental fairness[.]”); Daniels v. Williams, 474 U.S. 327, 331 (1986) (“[T]he Due Process Clause promotes fairness. . . ."); Landon v. Plasencia, 459 U.S. 21, 34-35 (1982) ("The role of the judiciary is limited to determining whether . . . procedures meet the essential standard of fairness under the Due Process Clause. . .."); Shaughnessy v. United States ex rel. Mezei, 345 U.S. 206, 212 (1953) (“[D]ue process of law” encompasses "traditional standards of fairness.").

${ }^{126}$ FED. R. CIV. P. 23 advisory committee's note to 1966 Amendment (Difficulties with the Original Rule).

${ }^{127} I d$.

${ }^{128}$ Amchem, 521 U.S. at 620.

${ }^{129} \mathrm{Id}$. at 621 .
} 
Revista Eletrônica de Direito Processual - REDP.

Rio de Janeiro. Ano 11. Volume 18. Número 1. Janeiro a Abril de 2017

Periódico Quadrimestral da Pós-Graduação Stricto Sensu em Direito Processual da UERJ

Patrono: José Carlos Barbosa Moreira. ISSN 1982-7636. pp. 68-122

www.redp.uerj.br

ticular, they must show, inter alia, that they"will fairly and adequately protect the interests of the class." ${ }^{130}$ As read by the highest federal tribunal, this "adequacy inquiry . . . serves to uncover conflicts of interest between named parties and the class they seek to represent." ${ }^{131}$ Only upon certification and this specific determination may the suit go forward.

The Supreme Court has explained how these controls safeguard theabsentees' well-being: A plaintiff class . . . cannot first be certified unless the judge, with the aid of the named plaintiffs and defendant, conducts an inquiry into the common nature of the named plaintiffs' and the absent [members'] claims, the adequacy of representation, the jurisdiction possessed over the class, and any other matters that will bear upon proper representation of the [absentees'] interest.See, e. g., . . Fed. Rule Civ. Proc. 23.Unlike a defendant in a civil suit, [an absent] class [member] is not required to fend for himself. . . . The court and named plaintiffs protect his interests. ${ }^{132}$

All in all, these checks should sufficientlyguaranteethat absentees will profit from the litigation.

If the complainants successfully pass the battery ofpreliminary tests, the tribunal must then "appoint class counsel." ${ }^{133}$ In so doing, it "may consider any . . . matter pertinent to counsel's ability to fairly and adequately represent the interests of the class. . .."134"If more than one adequate applicant seeks appointment, the court must appoint the applicant best able to represent the interests of the class." ${ }^{" 135}$ Consistently, the Ruledefines "Counsel's Duty" in the following terms:"Class counsel must fairly and adequately represent the interests of the class." 136

Moreover, judges become very engagedin a class action proceeding, more so than in an individual suit. They must constantly make sure to look after the welfare ofclass members. Thus:

\footnotetext{
${ }^{130}$ FED. R. CiV. P. 23(a)(4).

${ }^{131}$ Amchem, 521 U.S. at 625.

132 Phillips Petroleum v. Shutts, 472 U.S. 797, 809 (1985).

133FED. R. Civ. P. 23(g)(1).

${ }^{134}$ FED. R. CIV. P. 23(g)(1)(B).

135FED. R. CiV. P. 23(g)(2).

${ }^{136}$ Fed. R. CiV. P. 23(g)(4).
} 
Revista Eletrônica de Direito Processual - REDP.

Rio de Janeiro. Ano 11. Volume 18. Número 1. Janeiro a Abril de 2017

Periódico Quadrimestral da Pós-Graduação Stricto Sensu em Direito Processual da UERJ

Patrono: José Carlos Barbosa Moreira. ISSN 1982-7636. pp. 68-122

www.redp.uerj.br

In conducting [the] action . . . the court may issue orders that . . (B) require- to

protect class members and fairly conduct the action-giving appropriate notice to some or all class members of: (i) any step in the action; (ii) the proposed extent of the judgment; or (iii) the members' opportunity to signify whether they consider the representation fair and adequate, to intervene and present claims or defenses, or to otherwise come into the action. ... ${ }^{137}$

It may also "impose conditions on the representative parties or on intervenors; . .require that the pleadings be amended to eliminate allegations about representation of absent persons and that the action proceed accordingly; or . . deal with similar procedural matters." 138

In a parallel vein, Rule 23 compels the plaintiffs litigating under it, in contradistinction to their counterparts in an ordinary suit, to obtain judicial endorsement prior to settling, voluntarily dismissing, or compromising the claim. ${ }^{139}$ Furthermore, it obligates them to "file a statement identifying any agreement made in connection with [any such] proposal" and to send "notice in a reasonable manner to all class members who would be bound by the proposal."140،Any class member may," at this point, "object to the proposal [and] may [withdraw the objection] only with the court's approval." ${ }^{141}$ Most importantly, "[i]f the proposal would bind class members, the court may approve it only after a hearing and on finding that it is fair, reasonable, and adequate." ${ }^{142}$ With these constraints, the lawmeticulouslyupholds the due process entitlements of the entire membership.In the words of the Supreme Court, it specificallymanifests "concern . . . for the [absentees]" and a "continuing solicitude for their rights." ${ }^{143}$ At the end of the day, "an absent class-action [member] is not required to do anything.He may sit back and allow the litigation to run its course, content in knowing that there are safeguards provided for his protection." 144

\footnotetext{
${ }^{137}$ FED. R. CIV. P. 23(d)(1)(B).

${ }^{138}$ FED. R. CIV. P. 23(d)(1)(C-E).

${ }^{139}$ FED. R. CIV. P. 23(e).

${ }^{140}$ FED. R. Civ. P. 23(e)(3, 1).

${ }^{141}$ FeD. R. CiV. P. 23(e)(5).

${ }^{142}$ FED. R. CiV. P. 23(e)(2).

143 Phillips Petroleum v. Shutts, 472 U.S. 797, 810 (1985).

${ }^{144} I d$.
} 
Revista Eletrônica de Direito Processual - REDP.

Rio de Janeiro. Ano 11. Volume 18. Número 1. Janeiro a Abril de 2017

Periódico Quadrimestral da Pós-Graduação Stricto Sensu em Direito Processual da UERJ

Patrono: José Carlos Barbosa Moreira. ISSN 1982-7636. pp. 68-122

www.redp.uerj.br

To ascertainwhether aclass action infringes upon the entitlements of the passive class members, a Latin American tribunal would examine theinner mechanics too.It would,most probably, understand them as effectively devised to honor absentees' entitlements.In all likelihood, the strictures in place would sufficefor purposes of due process in Latin America, as in the United States.

Ultimately, defeated Latin Americanabsent class members, like their U.S. peers,could hardly cry "foul"ex post facto.After all, they wouldhave free-ridden on the plaintiffs' efforts, with a chance at compensation upon a favorable ruling, and would have benefited, throughout the proceedings, from a judge, a class attorney, and a representative solicitous, by law, of their welfare in relation to the affair at hand.The judiciary in Latin America would most likelyregard the entire arrangement as patently fair.In addition, it would almost certainly appreciate that this collective litigationhadenabled Latin American absentees tostake their claim to begin with, without having to travel northward,familiarize themselveswith thelegal system, hire a lawyer, and prosecute a separate complaint in the United States.

\section{Due Process And the Opt-Out Regime}

"Rule 23(b)(3)," which resulted from the 1966 revision and under which the proceedingswould unfold,"added to the complex-litigation arsenal class actions for damages designed to secure judgments binding all class members save those who affirmatively elected to be excluded. ${ }^{~}{ }^{145}$ Not surprisingly, it introduced a number of supplementalparameters precisely to enhance fairness towardabsentees.As noted in Part I, tribunals must verify, at the outset, "that the questions of law or fact common to class members predominate over any questions affecting only individual members, and that a class action is superior to other available methods for fairly and efficiently adjudicating the controversy." ${ }^{146}$ They must especially assess"the class members' interests in individually controlling the prosecution or defense of separate actions. . ..147

"For any class certified under Rule 23(b)(3), the court mustdirect to class members the best notice that is practicable under the circumstances, including individual notice to all mem-

${ }_{145}$ Amchem v. Windsor, 521 U.S. 591, 614-15 (1997).

${ }^{146}$ FED. R. CIV. P. 23(b)(3).

${ }^{147}$ FED. R. CIV. P. 23(b)(3)(A). 
Revista Eletrônica de Direito Processual - REDP.

Rio de Janeiro. Ano 11. Volume 18. Número 1. Janeiro a Abril de 2017

Periódico Quadrimestral da Pós-Graduação Stricto Sensu em Direito Processual da UERJ

Patrono: José Carlos Barbosa Moreira. ISSN 1982-7636. pp. 68-122

www.redp.uerj.br

bers who can be identified through reasonable effort." ${ }^{148}$ The Supreme Court has strictly con-

strued this command:"Individual notice must be sent to all class members whose names and addresses may be ascertained through reasonable effort."149،"The notice must," according to the provision itself, clearly and concisely state in plain, easily understood language:"

(i) the nature of the action;

(ii) the definition of the class certified;

(iii) the class claims, issues, or defenses;

(iv) that a class member may enter an appearance through an attorney if the member

so desires;

(v) that the court will exclude from the class any member who requests exclusion;

(vi) the time and manner for requesting exclusion; and

(vii) the binding effect of a class judgment on members. . . 150

The drafting Advisory Committee set forth this notification regime in order to ensurecompliance with due process:"This mandatory notice ..., together with any discretionary notice which the court may find it advisable to give . . ., is designed to fulfill requirements of due process to which the class action procedure is of course subject." ${ }^{\prime 151}$

In passing on the fairness of a judgment in a 23(b)(3) class action, a Latin American tribunal would have to take into accountthesespecial measuresconceived to keep an absent member abreast of the developments and to permithim or her to exit.It would quitecertainly view them as not only very protective of absentees but also as deliberately contrived for that purpose.The efforts undertaken by the framerson this front wouldalmost surelycome across as more than sufficient in a region that essentially sharesthedue processconcept with the United States.

The U.S. Supreme Courtconfronted, in Phillips Petroleum Co. v. Shutts, the argument"that the 'opt out' procedure ... is not good enough, and that an 'opt in' procedure is required to satisfy the Due Process Clause of the Fourteenth Amendment." ${ }^{152}$ For the sake of

\footnotetext{
${ }^{148}$ FED. R. CIV. P. 23(c)(2)(B).

149 Eisen v. Carlisle \& Jacquelin, 417 U.S. 156, 173 (1974).

${ }^{150}$ FED. R. CIV. P. 23(c)(2)(B)(i-vii).

${ }^{151}$ FED. R. CiV. P. 23 advisory committee's note to 1966 amendment (Subdivision (d)).

152 Phillips Petroleum v. Shutts, 472 U.S. 797, 811 (1985).
} 
Revista Eletrônica de Direito Processual - REDP.

Rio de Janeiro. Ano 11. Volume 18. Número 1. Janeiro a Abril de 2017

Periódico Quadrimestral da Pós-Graduação Stricto Sensu em Direito Processual da UERJ

Patrono: José Carlos Barbosa Moreira. ISSN 1982-7636. pp. 68-122

www.redp.uerj.br

clarity, it explained that"an 'opt in' provision would require that each class member affirmatively consent to his inclusion within the class." ${ }^{153}$ The oft-divided justices on this occasionunanimously "reject[ed] [the] contention that the Due Process Clause of the Fourteenth Amendment requires that absent [class members] affirmatively 'opt in' to the class, rather than be deemed members of the class if they do not "opt out."" 154 They retorted that a tribunal"may [indeed] exercise jurisdiction over the claim of an absent[ee]"155and held"that the protection afforded . . . class members . . . satisfies the Due Process Clause." ${ }^{156}$

The Supreme Courtargued that:"The interests of [absentees] are sufficiently protected by the forum ... when those [persons] are provided with a request for exclusion that can be returned within a reasonable time to the court." ${ }^{157}$ It elaborated its thinking as follows:

If the forum . .. wishes to bind an absent [class member] concerning a claim for money damages or similar relief at law, it must provide minimalprocedural due process protection.The [absentee] must receive notice plus an opportunity to be heard and participate in the litigation, whether in person or through counsel. . . The notice should describe the action and the plaintiffs' rights in it.Additionally, ... due process requires at a minimum that an absent [class member] be provided with an opportunity to remove himself from the class by executing and returning an "opt out" or "request for exclusion" form to the court.Finally, theDue Process Clause of course requires that the named plaintiff at all times adequately represent the interests of the absent class members. ${ }^{158}$

The justices underscored that class members acquiescebydeclining to bail out when allowed to do so.

[T] he "opt out" procedure . . is by no means pro forma, and . . . the Constitution does not require more to protect what must be the somewhat rare species of class member who is unwilling to execute an "opt out" form, but whose claim is nonetheless so important that he cannot be presumed to consent to being a member of the

\footnotetext{
${ }^{153} I d$.

${ }^{154} I d$. at 812 .

${ }^{155} \mathrm{Id}$. at 811 .

${ }^{156} I d$. at 815 .

${ }^{157} \mathrm{Id}$. at 814 .

${ }^{158} \mathrm{Id}$. at $811-12$.
} 
Revista Eletrônica de Direito Processual - REDP.

Rio de Janeiro. Ano 11. Volume 18. Número 1. Janeiro a Abril de 2017

Periódico Quadrimestral da Pós-Graduação Stricto Sensu em Direito Processual da UERJ

Patrono: José Carlos Barbosa Moreira. ISSN 1982-7636. pp. 68-122

www.redp.uerj.br

class by his failure to do so.[W]e do not think that the Constitution requires . . . sac-

rific[ing] the obvious advantages in judicial efficiency resulting from the "opt out" approach for the protection of [such a] rara avis. . . ${ }^{159}$

Naturally, the "advantages in judicial efficiency" inure mostly to the benefit ofabsentees.Therefore, these individuals can scarcely repudiate the judgment as unfair to them.

In all probability, Latin American judges would reason, along the lines of their U.S. colleagues, that the safeguards in place generally for class actions and particularly for those of the opt-out kind suffice.As a consequence, they would most likely conclude that Rule 23(b)(3) class actions, just as the comparable local suits referenced in Section E, comport with due process and, accordingly, with the public order.Once again, the same basic notion of due process should not yield different answers on either side of the border.

For allof thesereasons, Latin Americanabsent class members, like their U.S. counterparts, could notsubsequently remonstratewith just cause about the way in which theybecame part of the class. They would have learnedabout the litigation details and had a fair chance tostay on board or jump ship.An adjudicator in Latin America should rebuff anyremonstrations in this regard.

\section{SUMmons AND SERVICE}

Someone might argue that the Inter-American Convention on Letters Rogatory, which many Latin American countries, including all those specifically discussed in this article, andthe United Stateshave signed, would requireserving and summoning absent class members. ${ }^{160}$ Thistreatyindeed applies, by its own terms, to letters rogatory aiming at "service of process" and "summonses." ${ }^{161}$ Nonetheless, it evidently meansthose that seek to serve or summon the usual addressee, namely,the defendant, and does not mention any other party or person.The Additional Protocol to the Inter-American Convention on Letters Rogatory removes

\footnotetext{
${ }^{159} \mathrm{Id}$. at $813-14$.

${ }^{160}$ SeegenerallyGIDI,Antonio.The Recognition of U.S. Class Action Judgments Abroad: The Case of Latin America. In: 37 BRooK. J. INT’L L.893, 938-39 (2012). Disponível em http://brooklynworks.brooklaw.edu/mwginternal/de5fs23hu73ds/progress?id=lp9rk0xClhw11rBN6QS-o8Nxp2Beb4loaaBFfSfFWs4,\&dl. Acesso em 25.04.2017.

${ }^{161}$ Convención Interamericana sobre Exhortos o Cartas Rogatorias, art. 2, Jan. 30, 1975, 1438 U.N.T.S. 287, O.A.S.T.S. No. 43 ("notificaciones"; "emplazamientos"). The official English version speaks of "service of process" and "summonses." Inter-Am. Conv. Letters Rog., art. 2, Jan. 30, 1975, 1975 U.S.T. LEXIS 589, 1438 U.N.T.S. 287,O.A.S. T.S. No. 43.
} 
Revista Eletrônica de Direito Processual - REDP.

Rio de Janeiro. Ano 11. Volume 18. Número 1. Janeiro a Abril de 2017

Periódico Quadrimestral da Pós-Graduação Stricto Sensu em Direito Processual da UERJ

Patrono: José Carlos Barbosa Moreira. ISSN 1982-7636. pp. 68-122

www.redp.uerj.br

any doubt on the matter by annexing Form B, which expressly speaks of "service onthedefendant." ${ }^{\prime 62}$ Consistently, Miguel Ángel Narváez Carvajal's Manual on Rogatory Letters, which principally focuses on the Inter-American system, Latin America, and Ecuador, specifies that this kind of "international judicial cooperation" enables "national judges and tribunals ... to summon the defendant [through the] judicial organs of other states. . .."163

In re Vivendi Universalsupports this interpretation.The U.S. District Court for the Southern District of New Yorkspecifically refused to read into this kind of international accorda command to serve absentees in an action under Rule 23(b)(3).It held that "service of process in th[e] context [of the analogous Hague Service Convention] refers to the formal delivery of an initial pleading to an opposing party, i.e., the defendant[, and] cannot readily be thought of as a means of providing notice by plaintiff to a member of the plaintiff class."164

The question remains whetherdue process in itself, independently of international law, commandssummoning absentees.A summons under Federal Rule of Civil Procedure 4 would actually inform them less comprehensivelyabout the relevant aspects of the procedurethan the notification under Rule 23(c)(2)(B)(i-vii). The former wouldessentiallyexplicate the consequences of "failure to appear and defend"and"name the court and the parties," as well as "the plaintiff's attorney." ${ }^{165}$ The latter would, as already pointed out, describe“"the nature of the action," "theclass certified," and "the class claims,"along with the mechanics of participation and "exclusion" and "the binding effect of a class judgment."166

Of course, service of process would include the complaint, in addition to the summons. ${ }^{167}$ More importantly, it would take place personally, ${ }^{168}$ not just by mail.Neither of these advantages, however,justifies requiring the plaintiff to serve passive class membersbecause

162 Form. B, Anexo, Protocolo Adicional a la Convención Interamericana sobre Exhortos o Cartas Rogatorias, May 8, 1979, 1438 U.N.T.S. 322, O.A.S. T.S. No. 56 (“citación al demandado"). The official English version reads "service on [the addressee] as a defendant." Form. B, Annex Add. Proto. Inter-Am. Conv. Letters Rog., May 8, 1979, 1975 U.S.T. LEXIS 589, 1438 U.N.T.S. 322; O.A.S.T.S. No. 56.

${ }^{163}$ CARVAJAL,Miguel Ángel Narváez.Manual Sobre Exhortos y Cartas Rogatorias. Quito: Corte Nacional de Justicia, 2014,p. 26: "La cooperación judicial internacional [permite a] las juezas, jueces y tribunales nacionales . . citar al demandado [a través de los] órganos judiciales de otros Estados. . ..”.

${ }^{164}$ In re Vivendi Universal, 242 F.R.D. 76, 104 (S.D.N.Y. 2007).

165FED. R. Civ. P. 4(a)(1).

${ }^{166}$ FED. R. CIV. P. 23(c)(2)(B)(i-vii).

${ }^{167}$ FED. R. CIV. P. 4(c)(1).

${ }^{168}$ FED. R. CIV. P. 4(c)(2). 
Revista Eletrônica de Direito Processual - REDP.

Rio de Janeiro. Ano 11. Volume 18. Número 1. Janeiro a Abril de 2017

Periódico Quadrimestral da Pós-Graduação Stricto Sensu em Direito Processual da UERJ

Patrono: José Carlos Barbosa Moreira. ISSN 1982-7636. pp. 68-122

www.redp.uerj.br

they will obtainenough informationabout the dispute anyway andmay always ask for a copy of

the complaintand becausethe noticesent to themshould reliably reach them. The remaining controls under Rule 23 sufficientlyguard theirinterests.

In Phillips Petroleum v. Shutts, an undivided U.S. Supreme Courtrebuffed an attempt to guaranteeabsentees all of the due process protections of the defendants.It reasoned that a lawsuitburdensthe latter differently and more heavily than the former.

The burdens placed by a State upon an absent class-action [member] are not of the same order or magnitude as those it places upon an absent defendant.An out-of-state defendant summoned by a plaintiff is faced with the full powers of the forum State to render judgment against it.The defendant must generally hire counsel and travel to the forum to defend itself from the plaintiff's claim, or suffer a default judgment.The defendant may be forced to participate in extended and often costly discovery, and will be forced to respond in damages or to comply with some other form of remedy imposed by the court should it lose the suit.The defendant may also face liability for court costs and attorney's fees. These burdens are substantial. . . ${ }^{169}$

The justices observed that absentees did not find themselves ina situation as burdensome as that of their adversaries in the litigation.

Besides th[e] continuing solicitude for their rights [under Rule 23], absent ... class members are not subject to other burdens imposed upon defendants. They need not hire counsel or appear.They are almost never subject to counterclaims or crossclaims, or liability for fees or costs.Absent. . class members are not subject to coercive or punitive remedies.Nor will an adverse judgment typically bind an absent [member] for any damages, although a valid adverse judgment may extinguish any of the [member's] claims which were litigated. ${ }^{170}$

In Vivendi, the tribunalrejected precisely the claim that due process entitled absentees to a fullfledged summons:"[I]t makes little sense to evaluate a class member's due process right to

169 Phillips Petroleum v. Shutts, 472 U.S. 797, 808 (1985).

${ }^{170} I d$. at 810 . 
Revista Eletrônica de Direito Processual - REDP.

Rio de Janeiro. Ano 11. Volume 18. Número 1. Janeiro a Abril de 2017

Periódico Quadrimestral da Pós-Graduação Stricto Sensu em Direito Processual da UERJ

Patrono: José Carlos Barbosa Moreira. ISSN 1982-7636. pp. 68-122

www.redp.uerj.br

adequate notice in terms of whether the service requirements of Rule 4 of the Federal Rules of

Civil Procedure have been satisfied." 171

As a result, due processdoes not mandate serving absentees, whether in Latin America or in the United States.In general, itpermits binding them with all of the Rule 23 safeguards in place.A contrary construalcannot stand.

\section{E. LATIN AMERICAN REPRESENTATIVE LITIGATION}

\section{IN GENERAL}

Latin American tribunals would have more than the grounds just discussed to reject a public order challenge to the recognition of a Rule 23(b)(3) class action judgment. They could also point to existing homegrownsuits that operate essentially as class actions. In order to hold that the latter collidewith the public order, the judiciary wouldhave todeem,most improbably, that the former do too and dismiss them summarily upon each filing.

Lately, the entire region has actually been opening up to collective litigation in general, to a greater extent than Europe.At times, it has even exceededthe United States in this regard. ${ }^{172}$ In light of this trend, an adjudicatorin Latin Americashould not find U.S. class actions inherently aberrant or, at any rate, contrary tothe public order.

This Section will first examine suitsthat resemble Rule 23(b)(3) actions, that have recently emerged in many Latin American nations, andthatbind absentees who haveeither opted in rather informallyor simply failed to opt out.Then, it will consider suitsthat call to mind Rule 23(b)(2) actions or citizen suits, that exist everywhere in the continent, and that deprive the represented collectivity'sabsent members, who have not assented to the litigation, of their right to sue.Judges in Latin America could invoke all of these procedural devices in adjudginga final decision on collective damages from the United Statescompatible with any local notionof due process. On the same basis, they could reject any contention by a Latin American absentee, whether residing north or south of the border,that he or she could not have expected-or that

\footnotetext{
${ }^{171}$ In re Vivendi Universal, 242 F.R.D. 76, 104 (S.D.N.Y. 2007).

${ }^{172}$ Seegenerally OQUENDO, Ángel R.Upping the Ante: Collective Litigation in Latin America. In: Revista Quaestio Iuris, vol.04, nº1. ISSN 1516-0351 p.522-563. Disponível em: http://www.epublicacoes.uerj.br/index.php/quaestioiuris/article/view/10198/7976. Acesso em 25/04/2017.J. TRANSNAT'L L. 248, 280 (2009) [hereinafterOquendo (2009)].
} 
Revista Eletrônica de Direito Processual - REDP.

Rio de Janeiro. Ano 11. Volume 18. Número 1. Janeiro a Abril de 2017

Periódico Quadrimestral da Pós-Graduação Stricto Sensu em Direito Processual da UERJ

Patrono: José Carlos Barbosa Moreira. ISSN 1982-7636. pp. 68-122

www.redp.uerj.br

he or she would, in fairness, deserve an exemption from - the preclusive effect of the judgment.

\section{Suits Resembling 23(B)(3) Actions}

Latin Americahas startedauthorizing suits that aggregate similar, interrelated individualentitlements along the lines of Rule 23(b)(3).It usually refers to the underlying entitlements as "homogenous individual rights."Of the sevennations under consideration, five have taken this step.Two of these five jurisdictions, Mexico and Colombia, require an individual to opt in rather informally.In contrast, the other three, Panama, Peru, and Brazil, generally include him or her unless he or she opts out.

In Mexico, the Federal Code of Civil Procedure, as revised in 2011,provides foran actionfor the protection of "individual rights and interests . . pertaining to similarly situated individuals" $" 173$ and relating to consumer matters or to the environment. ${ }^{174}$ It grants standing to "the representative of the collectivity." ${ }^{175}$ Concerned persons may enter the suit "by expressly informing the representative by any means, " 176 perhaps even by email or orally. They will have a "right to compensation" only if they "belong to the collectivity,"177 possibly meaning that they must present the informal expression of intent just mentioned."The representative," in turn, represents "the collectivity and the members who have joinedthe action." ${ }^{178}$ Article 586 echoes the U.S. Federal Rules of Civil Procedure with the following language:"The representation" undertaken by a person or an organization in any kind of collective suit "shall be adequate."179

InColombia, Law 472 of 1998 purports to carry out the Constitution'smandate "to regulate group actions," 180 which "are filed by a plurality or by a number of persons who have sim-

\footnotetext{
${ }^{173}$ CD. Fed. Pro. CIV. (Mex.) (1943), art. 581(III) (“derechos e intereses individuales . . ., cuyos titulares son los individuos agrupados con base en circunstancias comunes").

${ }^{174} I d$. art. 578 ("en materia de relaciones de consumo de bienes o servicios, públicos o privados y medio ambiente").

${ }^{175} I d$. art. 585(II) ("El representante común de la colectividad”).

${ }^{176} I d$. art. 594 ("a través de una comunicación expresa por cualquier medio dirigida al representante”).

${ }^{177} I d$. ("derecho al pago que derive de la condena")("las personas que formen parte de la colectividad").

${ }^{178} \mathrm{Id}$. ("El representante ... representa[] a la colectividad y a cada uno de sus integrantes que se hayan adherido . . . a la acción.”).

${ }^{179} I d$. art. 586 ("La representación ... . deberá ser adecuada.").

${ }^{180}$ L. 472 (Colom.) (1998), art. 1 ("La presente ley tiene por objeto regular las acciones populares y las acciones de grupo de que trata el artículo 88 de la Constitución Política de Colombia.”).
} 
Revista Eletrônica de Direito Processual - REDP.

Rio de Janeiro. Ano 11. Volume 18. Número 1. Janeiro a Abril de 2017

Periódico Quadrimestral da Pós-Graduação Stricto Sensu em Direito Processual da UERJ

Patrono: José Carlos Barbosa Moreira. ISSN 1982-7636. pp. 68-122

www.redp.uerj.br

ilarly suffered individual harmstemmingfrom thesame source."181،The action,"pursuant to

Article 3, "shall be filedexclusively to establish liability and to securecompensation for the loss." ${ }^{182}$ Furthermore:"The judge shall ensure the respect of due process, procedural guaranties, and equality among the parties." 183

The enactment describes the representation at stakein these terms:"In a group action, the plaintiff . . . represents the other persons, who have individually suffered as a result of the allegedly injurious actions and who therefore need not sue separately or grant power of attorney." ${ }^{184}$ Membersof the groupmay sign up with a simplecommunication, in writing but without the ordinarily requisite notarization:

When the action is for injuries inflicted upon a plurality of persons and stemming from the same act or omission, ... those who suffered harm may become part of the suit . .. by submitting a document containing their name, identifying their injury and its source, and expressing their willingness to accept the judgment and to join the group that filed the complaint. ${ }^{185}$

In Panama,Chapter III of the 2007 Law 45, which amends Law 29 of 1996, entitles “one or more members of a group or class of persons who have suffered harm or prejudice stemming from aproduct or service"186 to lodge opt-out "consumer class actions."187"Upon admitting the complaint, the tribunal shall,"under Article 172(3), "registerit and publish an an-

${ }^{181} I d$. art. 3 ("Son aquellas acciones interpuestas por un número plural o un conjunto de personas que reúnen condiciones uniformes respecto de una misma causa que originó perjuicios individuales para dichas personas."). See alsoid. art. 46 ("Las acciones de grupo son aquellas acciones interpuestas por un número plural o un conjunto de personas que reúnen condiciones uniformes respecto de una misma causa que originó perjuicios individuales para dichas personas.").

${ }^{182} I d$. art. 3 ("La acción de grupo se ejercerá exclusivamente para obtener el reconocimiento y pago de indemnización de los perjuicios."). See alsoid. art. 46 ("La acción de grupo se ejercerá exclusivamente para obtener el reconocimiento y pago de indemnización de los perjuicios.”).

${ }^{183} \mathrm{Id}$. art. 5 ("El Juez velará por el respeto al debido proceso, las garantías procesales y el equilibrio entre las partes.").

${ }^{184} I d$. art. 48 ("En la acción de grupo el actor . . representa a las demás personas que hayan sido afectadas individualmente por los hechos vulnerantes, sin necesidad de que cada uno de los interesados ejerza por separado su propia acción, ni haya otorgado poder.”).

${ }^{185} \mathrm{Id}$. art. 55 ("Cuando la demanda se haya originado en daños ocasionados a un número plural de personas por una misma acción u omisión, .. . quienes hubieren sufrido un perjuicio podrán hacerse parte dentro del proceso ... mediante la presentación de un escrito en el cual se indique su nombre, el daño sufrido, el origen del mismo y el deseo de acogerse al fallo y de pertenecer al conjunto de individuos que interpuso la demanda. ...”).

186L. 45 (Pan.) (2007), art. 129 ("uno o más miembros, de un grupo o clase de personas que han sufrido un daño o perjuicio derivado de un producto o servicio.”).

${ }^{187} I d$. ("acciones de clase, en materia de consumo"). 
Revista Eletrônica de Direito Processual - REDP.

Rio de Janeiro. Ano 11. Volume 18. Número 1. Janeiro a Abril de 2017

Periódico Quadrimestral da Pós-Graduação Stricto Sensu em Direito Processual da UERJ

Patrono: José Carlos Barbosa Moreira. ISSN 1982-7636. pp. 68-122

www.redp.uerj.br

nouncement. . . in a nationally circulating newspaper so that ... the plaintiff and all persons

who belong to the group may appear to vindicate their rights, formulate arguments or participate in the suit." ${ }^{188}$ Significantly, Article 129(4) underscores that:"Any member who would like to exclude himself may do so until the scheduling of the preliminary hearing." ${ }^{189}$ Article 172(6) proclaims:"The judgment shall bind all the plaintiffs that belong to the group even if they have not intervened in the process." 190

Moreover, Panamanian Law 19 of 2008 creates a suit to vindicate homogeneous individual rights in international litigation.It incorporates into the Judicial CodeArticle 1421-I, which reads:"Upon a violation of similarly defined individual rights of the members of a group, collectivity, or class, the concerned persons themselves, their representative association, or a nongovernmental organization devoted to the defense of collective entitlements shall have standing to sue for the vindication of their homogeneous individual rights." ${ }^{191}$ The statute does not spell out (1) what notification the complainants must send to those they purport to represent, (2) whether absentees must include or exclude themselves into or out of the litigation, (3) how the proceedings will unfold, or (4) what res judicataconsequencesthe ultimaterulingwill have.Presumably, standard preclusion norms apply, foreclosing any additional litigation on the originalclaims.

In Peru, Article 131.1 of Law 29571, the Code of Consumer Protection and Defense, empowers the "National Institute for the Defense of Competition and for the Protection of Intellectual Property"192 "to prosecute suits to defend the collective interests of consumers," 193 as

\footnotetext{
${ }^{188}$ Id. art. 129 (3) ("El tribunal, al acoger la demanda, la . . . publicará edicto . . en un diario de reconocida circulación nacional, para que ... el demandante y todas las personas pertenecientes al grupo comparezcan a hacer valer sus derechos, a formular argumentos o a participar en el proceso.").

${ }^{189} \mathrm{Id}$. art. 129(4) ("El miembro de la clase que desee excluirse podrá hacerlo hasta antes de que se fije fecha para la audiencia preliminar.”).

${ }^{190} I d$. art. 129(8) ("La sentencia afectará a todos los demandantes que pertenezcan a dicho grupo, aunque no hayan intervenido en el proceso.").

${ }^{191}$ L. 19 (Pan.) (2008), art. 1421-I ("Cuando se lesionen derechos subjetivos individuales, provenientes de origen común y tengan como titulares a los miembros de un grupo, categoría o clase, los afectados, colectivos de afectados o las organizaciones no gubernamentales constituidas para la defensa de derechos colectivos estarán legitimados para promover la acción en defensa de los derechos individuales homogéneos.”).

192L. 29571, CD. Protección Def. Consumidor (Peru) (2010), art. 105 ("Instituto Nacional de Defensa de la Competencia y de la Protección de la Propiedad Intelectual (Indecopi)").

${ }^{193} I d$. art. 131.1 ("para promover procesos en defensa de intereses colectivos de los consumidores.").
} 
Revista Eletrônica de Direito Processual - REDP.

Rio de Janeiro. Ano 11. Volume 18. Número 1. Janeiro a Abril de 2017

Periódico Quadrimestral da Pós-Graduação Stricto Sensu em Direito Processual da UERJ

Patrono: José Carlos Barbosa Moreira. ISSN 1982-7636. pp. 68-122

www.redp.uerj.br

well as to "delegate [this] authority . . . to consumer associations,"194 but not to individu-

als.Under Article 131.3, this agency "represents all concerned consumers . . except those who declare expressly and in writing the desire not to vindicate their rights or to do so separately. . .."195 A non-appealable adjudication on the merits should bar all members of the group who have not opted out in this manner from litigating anew.

In addition, the Peruvian Constitutional Court has built an action to enforce homogenous individual rights under the Constitution into Article 60 of the Code of Constitutional Procedure.In 2008, it explained that in the face of "an unconstitutional state of affairs,"characterized by "a generalized violation of the fundamental rights of different persons," "196، "any person whose individual rights have been impinged upon may file a complaint [and] the effects of the decision ... may extend to other similarly situated persons. ..." ${ }^{197}$ According to the opinion, "[a] declaration of an unconstitutional state of affairs,essentially extends the effects of the decision to persons who were not plaintiffs, who did not otherwise participatein the suit that led to the declaration, but who find themselves in precisely the same situation that was held to be unconstitutional." 198

Obviously, Peru's justices were primarily thinking of a case in which the trial court determinesthat a "violation of a constitutional right" ${ }^{199}$ has occurred.Nonetheless, they shouldapproach the preclusive impact ofa contrary determinationidentically infairnessto the party accused of committing the infringement.Eventually, either the judicial or the legislative branch willhave to settle this question.In the meantime, the Peruvian judiciary shouldavoid the iro-

${ }^{194} I d$. ("delegar [esta] facultad ... a las asociaciones de consumidores").

${ }^{195} \mathrm{Id}$. art. 131.3 (El Instituto "representa a todos los consumidores afectados . . si aquellos no manifiestan expresamente y por escrito su voluntad de no hacer valer su derecho o de hacerlo por separado. ....").

196 [Lovón Ruiz-Caro v. Minis. Rel. Ext.,] Exp. No. 05287-2008-PA/TC (Trib. Const.) (Peru) (2009), § 2.3.2 ("estado de cosas inconstitucional") ("una violación generalizada de derechos fundamentales de distintas personas").

${ }^{197} I d$. §2.5.1(a) (“[C]ada persona afectada en sus derechos en forma individual puede presentar la demanda. . . .") ("[L]os efectos de la decisión sobre un caso particular pueden extenderse a otras personas en similar situación.").

${ }^{198} I d$. §2.3.2 ("La característica esencial de la declaración de una determinada situación como un estado de cosas inconstitucional consiste en extender los efectos de una decisión a personas que no fueron demandantes ni participaron en el proceso que dio origen a la declaratoria respectiva, pero que se encuentran en la misma situación que fue identificada como inconstitucional.”).

${ }^{199}$ Id. §2.5.1(a). 
Revista Eletrônica de Direito Processual - REDP.

Rio de Janeiro. Ano 11. Volume 18. Número 1. Janeiro a Abril de 2017

Periódico Quadrimestral da Pós-Graduação Stricto Sensu em Direito Processual da UERJ

Patrono: José Carlos Barbosa Moreira. ISSN 1982-7636. pp. 68-122

www.redp.uerj.br

nyof holdingthat Rule 23(c)(3)(B), which does afford the defendant equitable treatment in this sense, violates due process.

In Brazil, the Public Ministry, the government, state entities, and nongovernmental organizations may institute public civil actions to address moral and pecuniary injuries to, inter alia, "(I) the environment; (II) consumers; (III) urban order; [and] (IV) goods and rights with artistic, aesthetic, historic, touristic, and scenic value." ${ }^{200}$ The Consumer Defense Code's Title III, which generallycontrolsthese suits, ${ }^{201}$ allows the assertion of "homogenous individual interests or rights, which stem from a common origin." 202 Article 94 calls for notice on a generalized, rather than individualized, basis. "Upon the complaint's filing," it commands, "an announcement shall be published in an official periodical so that any interested individuals may intervene in the proceedings." 203

Article 103 describes "the res judicata effect" as "[e]rga omnes." ${ }^{204}$ Inasmuch as the latter Latin phrase means'concerning all,'the ultimate ruling precludes subsequent litigation by any of the represented persons. The provision adds a key qualification when it specifies that such preclusion will operate "solely for the benefit of all the victims and their survivors, in case the petitioners prevail." 205 Consequently, if the original plaintiffs lose, those they representedmay re-litigate their claims.

Brazilian lawmakers thus explicitly treadthe path hinted at by Peru's justices. They thus encounter theunfairness problemalready discussed.In any event, Brazil's judiciary will most likely gravitate, as much as its Peruvian counterpart, towarddeeming Rule 23(b)(3) actions, which treat the defendants fairly, consistent with due process. At any rate, it will very probably appreciate the various adjectivesafeguards, which Sections IV(B) and (C) dissected and

\footnotetext{
${ }^{200}$ L. 7347 (Braz.) (1985), art. 1 (“(I) [o] meio ambiente; (II) [o] consumidor; (III) [a] ordem urbanística; (II) [os] bens e direitos de valor artístico, estético, histórico, turístico e paisagístico”).

${ }^{201} I d$. art. 21 ("Aplicam-se à defesa dos direitos e interesses difusos, coletivos e individuais, no que for cabível, os dispositivos do Título III da lei que instituiu o Código de Defesa do Consumidor.") [“The provisions of Title III of the law that enacted the Consumer Defense Code shall apply, to the extent relevant, to the defense of diffuse, collective, and individual rights and interests."].

${ }^{202}$ L. 8078 (Braz.) (1990), art. 81(III) ("interesses ou direitos individuais homogêneos, assim entendidos os decorrentes de origem comum").

${ }^{203} I d$. art. 94.

${ }^{204}$ Id. art. 103 ("coisa julgada") ("erga omnes").

${ }^{205} I d$. ("apenas no caso de procedência do pedido, para beneficiar todas as vítimas e seus sucessores”).
} 
Revista Eletrônica de Direito Processual - REDP.

Rio de Janeiro. Ano 11. Volume 18. Número 1. Janeiro a Abril de 2017

Periódico Quadrimestral da Pós-Graduação Stricto Sensu em Direito Processual da UERJ

Patrono: José Carlos Barbosa Moreira. ISSN 1982-7636. pp. 68-122

www.redp.uerj.br

which are mostly unavailable under Brazilian law, as sufficiently protective of the entitlements and interests of absentees.

In light of these various suits, a tribunalfrom any of these countries or from elsewhere in the region willtend to regard Rule23(b)(3) actions ascompatiblewith the public order.It shouldviewthemas comparable enough to the local suitsto justify ruling that they do not contravene any of the relevantsystemic principles. The differences in the details should not affect the analysis.

Of course, Latin American absent class members seeking a second bite at the apple might press for the rejection of an adverse U.S.judgmentunless thejurisdiction at the receivingendbindsrepresented persons who have not explicitly extricated themselves from the suit.Thisposition, which would help claimants from Mexico and Colombia,does not sound very persuasive, though.After all, it construes as decisive a contingency that does notconcern the public order at all — to wit,how absentees partake in the ongoing litigation under thestatutory parameters in force locally.On the one hand, the aforementioned nations, which haveadopted an opt-in arrangement, could have instituted anopt-outregime instead without altering their constitutional or basic legal framework.Actually, the Mexican Congress originally considered and ultimately discarded a proposal that would have necessitated that a "member of the collectivity or group ... request his exclusion. ${ }^{206}$ On the other hand, countries without any legislation on point, like Venezuelaand Ecuador, may very well stillembrace such an approach.

Once again, judges may not resist recognition merely because the foreign statute applied differs from its domestic counterpart.They would have to ascertain, additionally, an unmistakable clash with long-standing, deep-rooted societal precepts.As in the death penalty example invoked in Section IV(A), the judicial inquiry would have to turn up a conflicting cardinal norm in the fundamental laws, constitution, ratified international treaties, etc.However, no such conflict existsvis-à-vis Rule 23(b)(3) actions.

Consistently, the United States District Court for the Southern District of New York rejected in Anwar v. Fairfield Greenwich, Ltd.,theobjection thattribunals in Spain would rely on

\footnotetext{
206 Iniciativa que Adiciona Disposiciones al Código Federal de Procedimientos Civiles (Acciones y procedimientos colectivos), Diputado Jaime Fernando Cárdenas Gracia (Mex.) (Feb. 9, 2010), art. 554 ("Cualquier miembro de la colectividad o grupo . . . podrápedir su exclusión. . . .”).
} 
Revista Eletrônica de Direito Processual - REDP.

Rio de Janeiro. Ano 11. Volume 18. Número 1. Janeiro a Abril de 2017

Periódico Quadrimestral da Pós-Graduação Stricto Sensu em Direito Processual da UERJ

Patrono: José Carlos Barbosa Moreira. ISSN 1982-7636. pp. 68-122

www.redp.uerj.br

the divergence between Spanish trans-individual suits and Rule 23(b)(3) actions to refuse to recognize the ultimate ruling in the latter type of procedure:

Defendants fail to identify an explicit conflict with [the] public [order] that would bar recognition of the judgment.The mere fact that [local] law does not explicitly embrace a foreign legal mechanism does not mean that it would find the judgment so repugnant that it would reject it as violating [the] public [order]. ${ }^{207}$

Absentees from Latin Americacould not rightfully decry the broad preclusive impactof a final decision on the merits as unfair.They couldhave hardly expectedthe U.S. class action, about which they would have individually received detailed information, to proceed as a comparable homegrownsuit, about which they would haverealistically known little.

In particular, a citizen and resident of practically any state in the region, including Mexico or Colombia, could neither persuasively nor credibly maintain that he or she did not read the notifying letter, assumed that she had to opt into the suit as undersome of the regionalenactments, and should consequently escape preclusion.Naturally, he or she could more convincingly object if his or her legal systemof origin would never terminate, based on an action that he or she did not explicitly approve, his or her right to sue.Nevertheless, the article will now show that virtually allLatin American jurisdictions permit the termination of the entitlement at issue under these circumstances.

\section{Suits ReSEMbling 23(B)(2) ACtions}

So-called diffuse rights suits, which resemble Rule 23(b)(2) actions and citizen suits, have developed dramatically in Latin America in the last three decades. ${ }^{208}$ They usually entitle any person, without a showing of individual injury, to litigateon behalf of society as a whole or a certain community for injunctive relief and frequentlydamages, in order to enforce diffuse or societal entitlements, such as those pertaining to the environment or collective cultural goods. The popular unconstitutionality action provides a special case in point.It empowersanybody to vindicate the polity's right to legislative or administrative adherence to the con-

\footnotetext{
${ }^{207}$ Anwar v. Fairfield Greenwich, Ltd., 289 F.R.D. 105, 118 (S.D.N.Y. 2013), partially aff'd sub. nom.Lomeli v. Sec. \& Inv. Co. Bahr., 546 F App'x 37 (2d Cir. 2013) (summary order), vacated on unrelated grounds sub. nom. St. Stephen's Sch. v. PricewaterhouseCoopers Accountants N.V., 570 F. Appx. 37 (2d Cir. 2014) (summary order).

${ }^{208}$ Seegenerally Oquendo, Ángel R. Latim American Law. ob. cit., note 172.
} 
Revista Eletrônica de Direito Processual - REDP.

Rio de Janeiro. Ano 11. Volume 18. Número 1. Janeiro a Abril de 2017

Periódico Quadrimestral da Pós-Graduação Stricto Sensu em Direito Processual da UERJ

Patrono: José Carlos Barbosa Moreira. ISSN 1982-7636. pp. 68-122

www.redp.uerj.br

stitutionandtohavea given lawor regulation pronounced unconstitutional prior toany applica-

tion.Independently of the entitlement exercised or the remedy requested, the final decisionnormally precludes everybody else fromprosecuting the claim anew, thereby extinguishing the previously held right to sue.

Sucha suitbears critical relevance to the discussion.Itactually operates more extremely than Rule 23(b)(3) actions inasmuch as it (1) bindsmostly a much larger number of nonconsenting individuals, (2) affords group members no individual noticeat all, and (3) accords them no opportunity to opt out.In light of the pervasiveness of this sortof procedure in Latin America, a tribunal there could hardly regard a Rule 23(b)(3) judgment as unfamiliar, let aloneas contrary to the public order.

Diffuse rights suits have had a long history in Latin America.They descend fromcivillawpopular actions. The latter date back at least to Roman law and had from the beginning a preclusive effect on the procedural entitlements of other community members.Title 23 of Book 47 of the Justinian Code, Corpus Juris Civilisdeals with such suits and proclaims:"If an action is repeatedly brought on the same cause and on the same fact, the ordinary exception of res judicata may be raised." 209

In the nineteenth century, the framers of Latin American Civil Codes regularly codified existing local law, which included the Law of Rome, both directly and through the Spanish Siete Partidas.Therefore, they implicitly incorporated the corresponding preclusionconsequences when they wrote in the popular actions already in force.For example, Chile's current Civil Code, drafted by Venezuelan Andrés Bello in 1855, institutes several such suits for very specific purposes, such as (1) to protect the life of unborn children, (2) to safeguard the right of way on public roads, (3) to remove objects that hang from buildings and that may fall on passersby, or (4) to set aside a potential harm to which an indeterminate number of people are

\footnotetext{
${ }^{209}$ CoRPus JURIS CIVILIS, 47.23 .3 (534) ("Sed si ex eadem causa saepius agatur [agetur], cum idem factum sit, exceptio vulgaris rei iudicatae opponitur.") "If a particular matter had been disposed of in a popular action, the respondent in a subsequent action based upon the same cause of action could plead res judicata." VAN DER VYVER Johan D.. Actiones Populares and the Problem of Standing in Roman, Roman-Dutch, South African and American Law, Cape Town:Acta Juridica, 1978, p. 191-192. Cf. 3 William BlaCKstone, ComMENTARIES*162 ("But if any one hath begun a qui tam or popular action, no other person can pursue it; and the verdict passed upon the defendant in the first suit is a bar to all others, and conclusive even to the king himself.").
} 
Revista Eletrônica de Direito Processual - REDP.

Rio de Janeiro. Ano 11. Volume 18. Número 1. Janeiro a Abril de 2017

Periódico Quadrimestral da Pós-Graduação Stricto Sensu em Direito Processual da UERJ

Patrono: José Carlos Barbosa Moreira. ISSN 1982-7636. pp. 68-122

www.redp.uerj.br

exposed. ${ }^{210}$ This piece of legislation was adopted verbatim by seven other nations(Colombia

(1860), Panama (1860, 1917), El Salvador (1860), Ecuador (1861), Venezuela (1863), Nicara-

gua (1871), Honduras $(1880,1906))$ and heavily influenced codification in Argentina (1876)

and Paraguay (1876). ${ }^{211}$

Since the 1990s, Latin America has experienced an explosion in this form of litigation. ${ }^{212}$ It has embraced not only derivative and associational suits, in which shareholders or associates proceed in the name of a corporation oran association, but also wide-ranging publiclaw actions for the enforcement of diffuse rights. ${ }^{213}$ Constitutions and statutes all over the continent featurethis variety ofsuit, including the unconstitutionality action cited earlier.They often explicitly underscore the preclusive effect with respect to all,viz.,erga omnes.Not surprisingly, every single one of the jurisdictions under consideration has participated in this transcontinental movement.

In Mexico, Article 580(I) of the Federal Code of Civil Procedure authorizes "collective actions . .. to enforce diffuse ... entitlements and interests, understood as those held by an indeterminate . . collectivity of factually . . similarly situated persons." ${ }^{214}$ It specifies that these suits, in which“the entitlements and interest pertain to an indeterminate collectivity,. . . aim at legally compelling the defendant to repair the harm to the collectivity either by reestab-

\footnotetext{
${ }^{210}$ CD. Civ. (Chile) (1857), arts. 75, 948, 2328, 2333. See alsoCD. Civ. (Colom.) (1873), arts. 91, 1005, 2355, 2359; CD. Civ. (Ecuad.) (2005), arts. 61, 990, 2228, 2236. The Panamanian Civil Code, in turn, authorizes popular actions to enforce the ban on the exaction of compound interestsand to remove or alter, as well as to recover damages caused by, a construction obstructing a public way. 625.CD. CIV. (Pan.) (1916), arts. 994-A, 625

${ }^{211}$ SeeOQUENDO, Ángel R. Latin American Law. ob. cit., note 11, at 437, 443 (reproducing LIRA, Bernardino Bravo. Civil Codification in Iberian America and on the Iberian Peninsula (1827-1917): National v. Europeanized Law. In:Fuentes ideológicas y normativas de la codificación latinoamericana. Buenos Aires: Universidad del Museo Social Argentino, 1992. See generally id. at 417 ("In the nineteenth century, some countries in the region simply enacted Bello's 1857 Code in toto, while others drew heavily from it.”).

${ }^{212}$ SeegenerallyOQUENDO, Ángel R.Upping the Ante: Collective Litigation in Latin America. ob. cit.,note 172.

${ }^{213}$ Seegenerallyid.

${ }^{214}$ CD. FED. Pro. Civ. (Mex.) (1943), art. 580(I) ("[L]as acciones colectivas son procedentes para tutelar . . . [d] erechos e intereses difusos y colectivos, entendidos como aquéllos de naturaleza indivisible cuya titularidad corresponde a una colectividad de personas, indeterminada o determinable, relacionadas por circunstancias de hecho o de derecho comunes.").
} 
Revista Eletrônica de Direito Processual - REDP.

Rio de Janeiro. Ano 11. Volume 18. Número 1. Janeiro a Abril de 2017

Periódico Quadrimestral da Pós-Graduação Stricto Sensu em Direito Processual da UERJ

Patrono: José Carlos Barbosa Moreira. ISSN 1982-7636. pp. 68-122

www.redp.uerj.br

lishing the status quo ante or through an alternative reparation for the impairment of the collectivity's rights or interests."215

Significantly, an adjudication on the merits wrests the right to litigatefrom all other members.For purposes of standing under Article 588(V), for instance, "[t]he matter may not have become res judicata as a result of a prior suit." ${ }^{216}$ In a parallel vein, Article 614 states that:"A non-appealable judgment shall have res judicata consequences." ${ }^{217}$ Presumably, preclusion applies even to a different suitor.Otherwise, the judiciary would run the risk of confronting an endless sequence of identical complaints.

In Brazil, 5(LXXIII) of the Constitution establishes that: "Any citizen may file a popular action seeking to annul either acts harmful to public property or state action that impinges upon the principle of administrative integrity, upon the environment, or upon historical or cultural goods." 218 The regulatory enactmentunderscores that: "The judgment shall constitute res judicata, erga omnes." 219 It excepts only "cases of dismissal for insufficiency of proof.",220 Accordingly, a final judicial decisionthat lies outside this exception will preclude anyone else from reigniting the controversy.

In Venezuela, Article 26 of the 1999 Constitution reads:“Any person shall have the right to vindicate his or her rights or interests, including those of a collective or diffuse nature, to enforce them, and to secure a prompt decision on point before a court of justice." 221 The 2010 Organic Law of the Supreme Court governs this type of litigation.In its Article 146 it recapitulates succinctly:"Any person shall have the right to sue for the protection of his or her collec-

\footnotetext{
${ }^{215} I d$. art. 581(I) (“[De] los derechos e intereses [es] titular . . . una colectividad indeterminada” y la acción "tiene por objeto reclamar judicialmente del demandado la reparación del daño causado a la colectividad, consistente en la restitución de las cosas al estado que guardaren antes de la afectación, o en su caso al cumplimiento sustituto de acuerdo a la afectación de los derechos o intereses de la colectividad. ...”).

${ }^{216} I d$. art. 588(V) ("[R] equisito[] de procedencia de la legitimación en la causa . . . : Que la materia de la litis no haya sido objeto de cosa juzgada en procesos previos.").

${ }^{217} I d$. art. 614 ("La sentencia no recurrida tendrá efectos de cosa juzgada.").

${ }^{218}$ Const. (Braz.) (1988), art. 5(LXXIII).

${ }^{219}$ L. 4717 (Braz.) (1965), art. 18.

${ }^{220} I d$.

${ }^{221}$ CONST. (Venez.) (1999), art. 26 ("Toda persona tiene derecho de acceso a los órganos de administración de justicia para hacer valer sus derechos e intereses, incluso los colectivos o difusos, a la tutela efectiva de los mismos y a obtener con prontitud la decisión correspondiente.”).
} 
Revista Eletrônica de Direito Processual - REDP.

Rio de Janeiro. Ano 11. Volume 18. Número 1. Janeiro a Abril de 2017

Periódico Quadrimestral da Pós-Graduação Stricto Sensu em Direito Processual da UERJ

Patrono: José Carlos Barbosa Moreira. ISSN 1982-7636. pp. 68-122

www.redp.uerj.br

tive or diffuse rights or interests." ${ }^{222}$ Under the terms of Article 153:"The summons shall be

published in a national or regional newspaper, depending on the facts of the case, so that anyone concerned may appear in court within ten days. ..."223 Article 154, labeled“Tacit Notification of Concerned Individuals,"warns that:"After the expiration of the deadlines set in the previous Article and upon the elapse of ten additional workdays, all concerned individuals shall be presumed to have been notified." ${ }^{224}$ The ultimate rulingshouldbind all other members of the collectivity and extinguishtheir procedural right to prosecute the claim.In this sense, pursuant to Article 150(3), "the complaint shall be declared inadmissible . . . in case of res judicata. . .."225

Moreover, the same statute also commands the Constitutional Chamber of the Supreme Court to hear"popular complaintsof unconstitutionality." ${ }^{226}$ In 2010, thisinstitution itself explained that "the nullity action of unconstitutionality is a popular action that may be filed by any citizen, i.e., any personis, in principle,procedurally interested or qualified enough to challenge laws . . .through a nullity action of unconstitutionality."227،"The effect of the judgment," according to the enactment, "shall be general in scope. . .."228

In Colombia, Law 472 of 1998controls "popular actions. . . for the protection of collective rights and interests."229“"Popular actions,"in the words of Article 9, "lie against any action or omission of the public authorities or of private persons that have violated or threaten to violate collective rights and interests." ${ }^{230}$ Article 21clarifies that:“"The members of the community may be notified through a means of masscommunication or any other effective mechanism, in view

\footnotetext{
${ }^{222}$ L. ORG. TRIB. SuPR. (Venez.) (2010), art. 146 ("Toda persona podrá demandar la protección de sus derechos e intereses colectivos o difusos.”).

${ }^{223} I d$. art. 153 ("El cartel de emplazamiento será publicado en un diario de circulación nacional o regional, según el caso, para que los interesados concurran dentro del lapso de diez días. ...”).

${ }^{224} I d$. art. 154 ("Cuando venzan los lapsos previstos en el artículo anterior, deberá dejarse transcurrir un término de diez días de despacho para que se entienda que los interesados han quedado notificados.”).

${ }^{225} I d$. art. 150(3) ("[S]e declarará la inadmisión de la demanda . . . [c]uando haya cosa juzgada.").

${ }^{226} I d$. art. 32 ("demanda popular de inconstitucionalidad").

227 [Asociación Civil Súmate v. Res. Consejo Nac. Elec.,] Sent. 796, (Sala Const.) (Trib. Supr.) (Venez.) (2010) ("[L]a acción de nulidad por inconstitucionalidad es una acción popular que puede ser ejercida por cualquier ciudadano, vale decir, que toda persona tiene, en principio, la cualidad o interés procesal para la impugnación de las leyes o actos con rango de ley, por medio de la acción de nulidad por inconstitucionalidad.”).

${ }^{228}$ L. ORG. TRIB. SuPR. (Venez.) (2010), art. 32 ("Los efectos de dicha sentencia serán de aplicación general.").

${ }^{229}$ L. 472 (Colom.) (1998), art. 2 ("Acciones populares . . para la protección de los derechos e intereses colectivos.”).

${ }^{230} I d$. art. 9 ("Las acciones populares proceden contra toda acción u omisión de las autoridades públicas o de los particulares, que hayan violado o amenacen violar los derechos e intereses colectivos.”).
} 
Revista Eletrônica de Direito Processual - REDP.

Rio de Janeiro. Ano 11. Volume 18. Número 1. Janeiro a Abril de 2017

Periódico Quadrimestral da Pós-Graduação Stricto Sensu em Direito Processual da UERJ

Patrono: José Carlos Barbosa Moreira. ISSN 1982-7636. pp. 68-122

www.redp.uerj.br

of all of the possible beneficiaries." "231“'A judgment upholding the plaintiffs' claim in a popular action may," asper Article 34, "grant an injunction, damages, . . . and an order to carry out actions necessary to reestablish the status quo ante. . .."232، The judgment,"under Article 35 ,"shall constitute res judicata with respect to the parties and the public in general."233

In addition, the Colombian Constitution permits "citizens" to lodge "unconstitutionality complaints . . against laws." ${ }^{234}$ Article 6 of the 1991 Decree 2067 cautions that:"Complaints againstlaws that have benefited from a judgment that constitutes res judicata shall be dismissed. . .."235"The Constitutional Court," in its own phrasing, "takes the norms submitted to it for examination and ascertainstheir validity or invalidity . . , with constitutional res judicata consequences ... ., withanerga omnes effect, and in a generally obligatory manner, thereby binding all persons and public authorities, with no exception whatsoever." ${ }^{236}$ Hence, a nonappealable determination on the merits unequivocally precludes any other citizen from launching a posterior suit on the same issues.

In Panama, Law 24 of 1995, in its Article 78, proclaims:“Any person may file, under this law, an environmental public action ... regarding not an individual or direct injury, but rather a threat or injury to diffuse interests or to the interests of a collectivity." 237 Article 3(4) defines a diffuse interest as "one that is disseminated throughout a collectivity; that pertains to each

\footnotetext{
${ }^{231} I d$. art. 21 ("A los miembros de la comunidad se les podrá informar a través de un medio masivo de comunicación o de cualquier mecanismo eficaz, habida cuenta de los eventuales beneficiarios.").

${ }^{232} I d$. art. 34 ("La sentencia que acoja las pretensiones del demandante de una acción popular podrá contener una orden de hacer o de no hacer, condenar al pago de perjuicios . . . y exigir la realización de conductas necesarias para volver las cosas al estado anterior. ...").

${ }^{233} \mathrm{Id}$. art. 35 ("La sentencia tendrá efectos de cosa juzgada respecto de las partes y del público en general.”).

${ }^{234}$ Const. (Colom.) (1991), art. 241 ("las demandas de inconstitucionalidad que presenten los ciudadanos contra las leyes").

235DECR. No. 2067 (Colom.) (1991), art. 6 ("Se rechazarán las demandas que recaigan sobre normas amparadas por una sentencia que hubiere hecho tránsito a cosa juzgada. . . .).

236 [Zapata Londoño v. art. 20, L. 393/1997,] Sent. C-600/98, (Ct. Const.) (Colom.) (1998), § VI.3 ("La Corte Constitucional, en lo que hace a las normas sometidas a su examen, define, con la fuerza de la cosa juzgada constitucional ...., su exequibilidad o inexequibilidad . . , con efectos erga omnes y con carácter obligatorio general, oponible a todas las personas y a las autoridades públicas, sin excepción alguna.”).

${ }^{237}$ L. 24 (Pan.) (1995), art. 78 ("En cumplimiento de la presente Ley, toda persona podrá interponer acción pública ambiental, sin necesidad de asunto previo cuando por su naturaleza no exista una lesión individual o directa, sino que atañe a los intereses difusos o a los intereses de la colectividad.”).
} 
Revista Eletrônica de Direito Processual - REDP.

Rio de Janeiro. Ano 11. Volume 18. Número 1. Janeiro a Abril de 2017

Periódico Quadrimestral da Pós-Graduação Stricto Sensu em Direito Processual da UERJ

Patrono: José Carlos Barbosa Moreira. ISSN 1982-7636. pp. 68-122

www.redp.uerj.br

member; and that does not derive from property entitlements, or concrete rights or actions. ${ }^{, 238}$ Once again, a presumption of generalized preclusion should attach to these suits.

Furthermore, constitutional Article 206(1) obligates the Plenary Chamber of the Panamanian Supreme Court to "decide ... upon the unconstitutionality of laws . . challenged by any person on procedural or substantive grounds. ${ }^{239}$ In 2009 , the body determined that res judicata forecloses instituting an unconstitutionality complaint upon a prior one when the two "involve the same facts and grounds." 240 It deliberated thus:

[T] he requirement of identity of parties - meaning that precisely the same individuals, who are bound by the decision that supposedly produced res judicata consequences, must be suing again - is often mentioned.Nonetheless, the area of constitutional law requires a certain modification because the issues transcend the legal relations among persons, touch upon purely legal matters, and produce consequences for the society as a whole, rather than exclusively for the complainants in the unconstitutionality action. ${ }^{241}$

As an upshot ofthe ultimate ruling uponthe first plaintiff's prosecution, all other citizens lose their right to prosecute the claim.In the quoted paragraph, Panama's justices make explicit what the other jurisdictions normally imply, to wit, that the final decision in a collective action may preclude someone who is not, strictly speaking, a party.

In Peru, Article 40 of the Code of Constitutional Procedureannouncesthat "any person may file for a writ of protection when a threat to or a violation of environmental or other diffuse rights that have constitutional stature is at stake. . ." ${ }^{242}$ The judge may approve"a declara-

\footnotetext{
${ }^{238} I d$. art. 3(4) ("aquel que se encuentra diseminado en una colectividad, corresponde a cada uno de sus miembros y no emana de títulos de propiedad, derechos o acciones concretas.").

${ }^{239}$ Const. (Pan.) (1972), art. 206(1) ("decidirá . . . sobre la inconstitucionalidad de las Leyes . . . que por razones de fondo o de forma impugne ante ella cualquier persona.”).

240 [Jované de Puy v. art. 233, Cd. Electoral], Exp. No. 937-08, (Pleno) (Ct. Supr.) (Pan.) (2009) ("contengan los mismos hechos o fundamentos").

${ }^{241} I d$. ("[S]e habla del requisito de identidad de partes, que alude a la concurrencia al proceso de los mismos sujetos vinculados con la decisión que da lugar a la supuesta cosa juzgada. Sin embargo, en este punto el hecho de tratarse de la rama constitucional produce cierta modificación, ya que en este ámbito del derecho, las cuestiones trascienden las relaciones jurídicas entre personas para versar aspectos netamente de derecho, produciendo consecuencias a todo el conglomerado social y no exclusivamente al o los promotores de la acción de inconstitucionalidad.").

242L. 28237, CD. Pro. Const. (Peru) (2004), art. 40 ("Asimismo, puede interponer demanda de amparo cualquier persona cuando se trate de amenaza o violación del derecho al medio ambiente u otros derechos difusos
} 
Revista Eletrônica de Direito Processual - REDP.

Rio de Janeiro. Ano 11. Volume 18. Número 1. Janeiro a Abril de 2017

Periódico Quadrimestral da Pós-Graduação Stricto Sensu em Direito Processual da UERJ

Patrono: José Carlos Barbosa Moreira. ISSN 1982-7636. pp. 68-122

www.redp.uerj.br

tion of nullity," "restitution of the status quo ante," or an injunction, ${ }^{243}$ as well as "monetary

compensation." ${ }^{244}$ Article 6, for its part, stresses that "a final decision"amounts to"res judica-

ta."245"The judgment" in these suits, the Peruvian Constitutional Court has written, "will have an effect on 'all other members of the collectivity who find themselves in a situation identical to that of the person who brought the action in the first place.'In consequence, the effect of the decision transcends the individual or group that filed the complaint." ${ }^{246}$ Coincidentally, Peru'sjustices have observed that the "the class action [in the United States is] related"to"diffuse rights" 247 and that the U.S. approach to adequate representation is not "foreign to [Peru's] constitutional order."248

ThePeruvian Code of Constitutional Procedurealso regulates popular and unconstitutionality actions. ${ }^{249}$ The former allow"any person" 250 to dispute the constitutionality or legality of administrative regulations. ${ }^{251}$ The latter enablea group of at least "five thousand citizens" 252 to contest the constitutionality of laws. ${ }^{253} \mathrm{~A}$ final decision on the merits in these suits "constitutes res judicata and therefore. . .has general effects." 254

In Ecuador, Article 43 of the 1999 Environmental Management Act informs that"persons, legal entities, [and] groupsof people united by a common interest and directly affected by the

que gocen de reconocimiento constitucional. ...”). "A writ-of-protection (amparo) action ... shall lie against acts or omissions that stem from any authority, official, or person and that encroach upon or threatens ... constitutionally recognized rights." Const. (Peru) (1993), art. 200(2) ("La Acción de Amparo . . . procede contra el hecho u omisión, por parte de cualquier autoridad, funcionario o persona, que vulnera o amenaza los . . . derechos reconocidos por la Constitución.”).

${ }^{243}$ L. 28237, CD. Pro. Const. (Peru) (2004), art. 55 (“[d]eclaración de nulidad,” “[r]estitución . . ordenando que las cosas vuelvan al estado en que se encontraban," "[o]rden y definición precisa de la conducta a cumplir").

${ }^{244} I d$. art. 59 ("prestación monetaria").

${ }^{245} \mathrm{Id}$. art. 6 ("[L]a decisión final" "adquiere . . . autoridad de cosa juzgada.").

246 [Lovón Ruiz-Caro v. Minis. Rel. Ext.,]Exp. No. 05287-2008-PA/TC (Trib. Const.) (Peru) (2009), § 2.5.1(a) (quoting MAC-GREGOR,Eduardo Ferrer; FAVELA, Jose Ovalle.Juicio de amparo e interés legítimo: la tutela de los derechos difusos y colectivos. Ciudad de Mexico: Porrúa, 2003, p. 12. See also [Viuda de Mariátegui e Hijos v. S.U.N.A.T. \& T.F., S.A.,] Exp. No. 04878-2008-PA/TC (Trib. Const.) (Peru) (2009), § 2.5.1(a).

247 5270-2005-PA/TC (Trib. Const.) (Peru) (2006), 3 (\$13) (“[L]a acción colectiva (class action) [está] relacionada con los derechos difusos.").

${ }^{248} I d$. at 4 ( $\left.\$ 14\right)$ ("ajena a nuestro ordenamiento constitucional”).

${ }^{249}$ L. 28237, CD. Pro. Const. (Peru) (2004), Tít. VI-VIII.

${ }^{250} I d$. art. 84 .

${ }^{251} I d$. art. 76.

${ }^{252}$ Const. (Peru) (1993), art. 203(5).

253 L. 28237, CD. PRo. Const. (Peru) (2004), art. 77.

${ }^{254}$ Id. art. 82 ("tiene[] autoridad de cosa juzgada, por lo que ... produce[] efectos generales"). See also id. art. 81 ("Las sentencias fundadas recaídas en el proceso de inconstitucionalidad ... [t]ienen alcances generales. . . .") ("Las sentencias fundadas recaídas en el proceso de acción popular . . [ [t]ienen efectos generales.”). 
Revista Eletrônica de Direito Processual - REDP.

Rio de Janeiro. Ano 11. Volume 18. Número 1. Janeiro a Abril de 2017

Periódico Quadrimestral da Pós-Graduação Stricto Sensu em Direito Processual da UERJ

Patrono: José Carlos Barbosa Moreira. ISSN 1982-7636. pp. 68-122

www.redp.uerj.br

injurious action or omission may sue ... for damagesin relation to any sanitary or environmental harm." ${ }^{255}$ Itemphasizes that environmental rights are "collective" and "shared by the community" and explicates "diffuse interest[s]," somewhat confusingly, as "homogeneous and indivisible interests held by indeterminate groups of individuals tied by common circumstances. ${ }^{256}$ Presumably, res judicata principles apply, so that a firm judicial rulingbars any subsequent litigation.

Similarly, Ecuadorian unconstitutionality suits offer anybody so inclined the meansto question the constitutionality of unapplied laws and regulations. ${ }^{257}$ The Organic Act on Judicial Guaranties and Constitutional Review spells out theerga omnes preclusive consequences.As articulated in Article 95:"Judgments issued in the exercise of abstract constitutional review shall constitute res judicata and shall have a general and prospective effect." ${ }^{258}$ Upon analyzing this provision, Álvaro Gutiérrez Godoy "conclude[s]—on the basis of the statute and in expectation of the necessary case-law development - that the Ecuadorian unconstitutionality declaration brings about the banishment, from the legal order, of the challenged law and the establishment of constitutional res judicata with general and prospective effect (erga omnes and ex nunc)." 259

All of these suits bear a resemblance to Rule 23(b)(2) actions, as well as citizen suits, in that they turn on a genuinely collective assertion. While they thus diverge from Rule 23(b)(3)actions, which aggregate a number of similar, interrelated individual claims, they ob-

\footnotetext{
255L. 77, L. Gestión Ambiental (Ecuad.) (1999), art. 43 ("Las personas naturales, jurídicas o grupos humanos, vinculados por un interés común y afectados directamente por la acción u omisión dañosa podrán interponer ante el Juez competente, acciones por daños y perjuicios y por el deterioro causado a la salud o al medio ambiente incluyendo la biodiversidad con sus elementos constitutivos.”).

${ }^{256} I d$., "Glosario de Definiciones" ("Inter[eses] Difuso[s]") ("intereses homogéneos y de naturaleza indivisible, cuyos titulares son grupos indeterminados de individuos ligados por circunstancias comunes.”).

${ }^{257}$ SeeConst. (Ecuad.) (2008), art. 436(2); L. OrG. Garantías Jurisdiccionales y Control Const. (Ecuad.) (2009), art. 98.

258 L.Org. Garantías Jurisdiccionales y Control Const. (Ecuad.) (2009), art. 95 ("Las sentencias que se dicten en el ejercicio del control abstracto de constitucionalidad surten efectos de cosa juzgada y producen efectos generales hacia el futuro.”).

${ }^{259}$ GODOY,Álvaro Gutiérrez.El control constitucional en Ecuador y Colombia: un análisis comparado. In:IURIS Dicto REV. COLEGIO JURIS. 55,56-57 (2009). Disponível em http://revistas.usfq.edu.ec/index.php/iurisdictio/article/view/687/759. Acesso em 25/04/2017. ("De lo anterior podemos concluir que, basados en la normativa y a la expectativa del necesario desarrollo jurisprudencial, para el caso ecuatoriano la declaratoria de inconstitucionalidad conlleva a la desaparición del ordenamiento jurídico de la norma acusada, haciendo tránsito a cosa juzgada constitucional, con efectos generales (erga omnes) y hacia el futuro (ex nunc).").
} 
Revista Eletrônica de Direito Processual - REDP.

Rio de Janeiro. Ano 11. Volume 18. Número 1. Janeiro a Abril de 2017

Periódico Quadrimestral da Pós-Graduação Stricto Sensu em Direito Processual da UERJ

Patrono: José Carlos Barbosa Moreira. ISSN 1982-7636. pp. 68-122

www.redp.uerj.br

viously may matter enormously to the people concerned.For example, someone may understandably care about the option to proceed against the pollution of a nearby communal lake as much as, or even more than, against the contamination of her backyard.

More importantly, the ultimate ruling in a diffuse rights suitdoesdepriveabsent community members of an individual entitlement, namely, the right to sue.It robs them, so to speak, of their day in court.Upon a definitive judgment, absenteesindividually lose the right to litigate (1) on their substantive collective entitlements in this kind of litigationand (2) on their substantive individual entitlementsin a Rule 23(b)(3) action.

For present purposes, a final decision in a diffuse rights suit effectively differs from one in a Rule 23(b)(3) class action only in the minimal respect just discussed:The former entails a loss of an individual procedural entitlement related to a collective substantive entitlement, the latter that of an individual procedural entitlement related to an individual substantive entitlement.Latin American judges could only arbitrarily find an infringement upon due process and the public order in one instance, but not in the other.Most likely, they wouldnot do so.

Accordingly, absentees from Latin America could not really complain. They could not truthfully say that back home they would never face preclusion through an action that they did not lodgeor at least consentto.After all, a diffuse rights suit precludes the entire citizenry in precisely this manner.And it does so ever more frequently, in virtue of its increased availability and popularity. ${ }^{260}$

\section{F. SUMmary}

Section A defined the concept of public order, which incorporates that of due process, and summarized the ensuing discussion.SectionsB and $\mathrm{C}$ maintained, respectively, that a tribunal in Latin Americawould very probably holdthat U.S. class action judgments in general and thosepronounced under Rule 23(c)(3)(B) in particular treat absent class members fairly and cohere with these two cardinal notions.Section D then demonstrated that absentees possess no right to a summons or service.As explained in Section E's various subdivisions, theholdingon fairness and coherence would find further support in the availability ofhomogenous individual rights suits, which recall Rule 23(b)(3)actions and bindabsentees whohave either opted in ra-

${ }^{260}$ Seegenerally OQUENDO, Ángel R. Upping the Ante: Collective Litigation in Latin America. ob. cit.,note 172. 
Revista Eletrônica de Direito Processual - REDP.

Rio de Janeiro. Ano 11. Volume 18. Número 1. Janeiro a Abril de 2017

Periódico Quadrimestral da Pós-Graduação Stricto Sensu em Direito Processual da UERJ

Patrono: José Carlos Barbosa Moreira. ISSN 1982-7636. pp. 68-122

www.redp.uerj.br

ther informally or simply failed to opt out.Moreover, it would attain definitive confirmation in the fact that Latin American analogues to Rule 23(b)(2) actions and citizen suits invariably wrest the right to sue from the represented collectivity'snon-assentingabsent members. At the outset, Part IVnoted that a refusal of recognition would, in effect, deprive defendants themselves of due process, as well as discriminate against them.As a whole, it emphasized that absentees from Latin America, even those who have always resided there,could not reject thefinal decision's broad res judicataimpactas unfair because they would have taken a free ride on the litigation with perhaps their only realisticchance atcompensation, would have benefited from a wide array of safeguards, including the right to notice and to exit, and could have faced preclusion under similar circumstances in their homeland.

\section{CONCLUSION}

The discussion started by imagining a concrete situation in which a Latin American tribunal might confront the question whether to recognize aU.S. group judgment for damages.It posited as the most likely (and yet rather improbable) scenario one in which absent class memberslauncha substantively identical complaint in Latin America upon losing on the merits in the United States.In the end, these individuals will probably not embark upona path of renewed litigation because of the overarchingcivil-law obstacles in the way and the high chance of dismissal either forlack of jurisdiction or for expiration of the statute of limitations.In any event, a Latin American adjudicator would, in all likelihood, dismissany such suit in deference to the final decision of the U.S. court.

Part Illisted the following as the main conditions for recognition in Latin America.

(1) Reciprocity from the State of Origin

(2) Jurisdiction of the Foreign Court over the Matter

(3) Sufficiency of Service and Defense Opportunities

(4) Finality of the Judgment

(5) Absence of Any Pending Similar Domestic Suit

(6) Respect for Areas of Exclusive National Jurisdiction

(7) Compatibility with the Public Order 
Revista Eletrônica de Direito Processual - REDP.

Rio de Janeiro. Ano 11. Volume 18. Número 1. Janeiro a Abril de 2017

Periódico Quadrimestral da Pós-Graduação Stricto Sensu em Direito Processual da UERJ

Patrono: José Carlos Barbosa Moreira. ISSN 1982-7636. pp. 68-122

www.redp.uerj.br

It identified a presumption in favor of enforcing judgments from abroad and then showed that the relevant legislation in Mexico, Brazil, Venezuela, Colombia, Panama, Peru, and Ecuador incorporates some or all of these items.

Next, Part III demonstrated that the ultimate ruling in a U.S. class proceedingwould meet the first six requirements.Part IV and its various segments, in turn, maintained that it would satisfy the seventh too.They defined the public order, which includes due process, and explained that a collective compensationjudgment from the United Stateswould cohere with both notions.In particular, it would rest on a number of safeguards for class actions generally and for those filed under Rule 23(b)(3) specifically.

Accordingly, a Latin American judge wouldalmost certainly agree with the U.S. Supreme Court that the opt-out regime fully comports with due process, aconceptthat has traveled across the border to Latin America, preserving its essential components intact.Moreover, he or she could point to regional suitspermitting, along the lines of Rule 23(b)(3), the aggregation of similar,interrelated individual claims of non-partieswho acquiesceeither by opting in rather informally or simply by failing to opt out.Finally, he or she could note that diffuse rights suits, which resemble Rule 23(b)(2) actions andexistthroughout the continent, invariably bind absentees who have in no way consented or even received individual notice.

The judiciary in the United States should, in principle, allow Latin American citizens into large representative suits for economic indemnification.Naturally, it should approach the presence of other foreigners just as openly, conducting a comparative law analysis analogous to that undertaken in this article.After all, the pursuit of justice for all demands the inclusion, across the board,of the traditionally excluded.

\section{BIBLIOGRAPHICAL REFERENCES}

BLACK'S LAW DICTIONARY ONLINE SECOND EDITION. Disponível em: http://thelawdictionary.org/personal-action/, acesso em 18/02/2017.

CARVAJAL, Miguel Ángel Narváez. Manual Sobre Exhortos y Cartas Rogatorias. Quito: Corte Nacional de Justicia, 2014. 
Revista Eletrônica de Direito Processual - REDP.

Rio de Janeiro. Ano 11. Volume 18. Número 1. Janeiro a Abril de 2017

Periódico Quadrimestral da Pós-Graduação Stricto Sensu em Direito Processual da UERJ

Patrono: José Carlos Barbosa Moreira. ISSN 1982-7636. pp. 68-122

www.redp.uerj.br

DODSON, Scott. Comparative Convergences in Pleading Standards. In: 158 U. PA. L. REV. 441, 443 (2010).

GIDI, Antonio. The Recognition of U.S. Class Action Judgments Abroad: The Case of Latin America. In: 37 BROOK. J. INT'L L. 893, 938-39 (2012). Disponível em http://brooklynworks.brooklaw.edu/mwginternal/de5fs23hu73ds/progress?id=lp9rk0xClhw11rBN6QSo8Nxp2Beb4loaaBFfSfFWs4,\&dl. Acesso em 25.04.2017

LIRA, Bernardino Bravo. Civil Codification in Iberian America and on the Iberian Peninsula (1827-1917): National v. Europeanized Law. In: Fuentes ideológicas y normativas de la codificación latinoamericana. Buenos Aires: Universidad del Museo Social Argentino, 1992.

OQUENDO, Ángel R. Latin American Law. Minnesotta: West Academic, 2011, 2. ED.

OQUENDO, Ángel R. Upping the Ante: Collective Litigation in Latin America. In: Revista Quaestio Iuris, vol.04, nº1. ISSN 1516-0351 p.522-563. Disponível em: http://www.epublicacoes.uerj.br/index.php/quaestioiuris/article/view/10198/7976. Acesso em 25/04/2017.

VAN DER VYVER Johan D.. Actiones Populares and the Problem of Standing in Roman, Roman-Dutch, South African and American Law. Cape Town: Acta Juridica, 1978.

MAC-GREGOR, Eduardo Ferrer; FAVELA, Jose Ovalle. Juicio de amparo e interés legítimo: la tutela de los derechos difusos y colectivos. Ciudad de Mexico: Porrúa, 2003

GODOY, Álvaro Gutiérrez. El control constitucional en Ecuador y Colombia: un análisis comparado. In: Iuris Dicto Rev. Colegio Juris. 55, 56-57 (2009). Disponível em http://revistas.usfq.edu.ec/index.php/iurisdictio/article/view/687/759. Acesso em 25/04/2017. 